\title{
Investment, Idiosyncratic Risk, and Ownership
}

\author{
Vasia Panousi Dimitris Papanikolaou*
}

October 28, 2009

\begin{abstract}
We document a significant negative effect of idiosyncratic stock-return volatility on investment. We address the endogeneity problem of stock return volatility by instrumenting for volatility with a measure of a firm's customer base concentration. We propose that the negative effect of idiosyncratic risk on investment is partly due to managerial risk aversion, and find that the negative relationship between idiosyncratic uncertainty and investment is stronger for firms with high levels of insider ownership. Several mechanisms can mitigate this effect namely the use of option-based compensation and shareholder monitoring. We find that the investment-idiosyncratic relationship is weaker for firms that make use of option-based compensation, and insider ownership does not matter for firms primarily held by institutional investors.
\end{abstract}

*Federal Reserve Board, vasia.panousi@frb.gov, and Kellogg School of Management, d-papanikolaou @kellogg.northwestern.edu. We would like to thank Snehal Banerjee, Gadi Barlevy, Luca Benzoni, Paco Buera, Jeff Campbell, Andrea Eisfeldt, Jiro Kondo, Guido Lorenzoni, Byron Lutz, Jae Sim, Harald Uhlig, Toni Whited, Egon Zakrajsek, and the seminar participants at the Federal Reserve Board, the Chicago Fed, the Kellogg School of Management, Michigan State University, and MIT for very useful comments and discussions. The views presented are solely those of the authors and do not necessarily represent those of the Board of Governors of the Federal Reserve System or its staff members. Dimitris Papanikolaou would like to thank the Zell Center for financial support. 


\section{Introduction}

We find a significant negative relationship between the volatility of idiosyncratic risk and the investment of publicly traded firms in the United States. We provide evidence in support of a causal relationship by instrumenting for a firm's idiosyncratic volatility with the concentration of the firm's customer base. The relationship is stronger for firms with high levels of insider ownership and weaker for firms with a convex executive compensation schedule. We interpret this negative relationship as the result of managerial risk aversion, in that managers may be reluctant to undertake new projects when idiosyncratic risk is high.

Neoclassical finance theory predicts that only the systematic component of risk is relevant for investment decisions, since firm owners are diversified and managers maximize shareholder value. Nonetheless, and consistent with empirical evidence, agency theory suggests that the managers who undertake investment decisions usually hold a substantial stake in the firm for incentive purposes. Consequently, managers may underinvest, since high idiosyncratic risk projects increase the volatility of their consumption stream. If this is the case, then the component of risk which would disappear under portfolio diversification will be relevant for investment decisions. In fact, proponents of option-based compensation have used this argument to justify providing executives with some measure of downside protection, as a compromise between supplying incentives and mitigating risk-averse behavior. Alternatively, strong monitoring may dampen this wedge between managers' and shareholders' valuation of investment projects.

Our first main result concerns the negative relationship between idiosyncratic risk and the investment of public firms in the US. We decompose stock-return volatility into a systematic and a firm-specific component, and we use the latter as our measure of idiosyncratic risk. We find that higher idiosyncratic volatility is associated with lower investment. Moreover, higher idiosyncratic volatility is associated with lower payout and increased cash holdings, evidence consistent with a precautionary savings motive. 
Two concerns prevent us from interpreting the negative correlation between investment and idiosyncratic volatility as a causal relationship. First, idiosyncratic volatility could be a proxy for a firm's growth opportunities, inducing omitted variable bias, since Tobin's $\mathrm{Q}$ is measured with error. Second, investment decisions may affect stock return volatility, since they alter the mix of growth options and assets in place, and the former are more volatile than the latter. We address the first concern by considering two alternative measures of growth opportunities: the first is constructed from analyst forecasts based on Bond and Cummins (2004), and the second is constructed from stock return correlations based on Kogan and Papanikolaou (2009). As a separate exercise, we also follow Erickson and Whited (2000) and deal with measurement error in Tobin's $Q$ directly in the estimation,

We address the endogeneity of stock-return volatility by instrumenting for it with a measure of how concentrated a firm's customer base is. Firms that sell to few customers cannot diversify demand shocks for their product across their customers, and will thus be riskier. To the extent that some of these demand shocks are idiosyncratic, the firm will face higher idiosyncratic risk. Our identification assumption is that, controlling for the level of sales, investment decisions do not affect how concentrated a firm's customer base is. We find that, in both cases, idiosyncratic volatility remains a statistically significant predictor of investment and thus conclude that the relationship is likely to be causal.

After concluding that idiosyncratic volatility does not proxy for unobserved growth opportunities, we proceed to explore the implications of agency theory. If the effect is due to managerial risk aversion, we expect it to be stronger in firms with higher levels of insider ownership and weaker in firms that make more use of options in their compensation schemes. Indeed, we find that the negative relationship between investment and idiosyncratic risk is strongest for firms where insiders hold a higher fraction of the shares. This effect is partially mitigated by convex compensation contracts: controlling for the level of insider ownership, firms which provide compensation contracts that are more convex, and therefore increase in value with volatility, display investment behavior that is not sensitive to idiosyncratic risk. 
In addition, we explore a related prediction, which is related to costs of external finance. Froot, Scharfstein and Stein (1993), among others, show that firms who face convex costs of external finance may behave in a risk-averse fashion, even if managerial preferences are risk-neutral. We use two variables to measure the likelihood of a firm being financially constrained: the Whited and $\mathrm{Wu}$ (2006) index and whether a firm is assigned a credit rating by Standard and Poor's. We find that the effect is indeed stronger for firms that are more likely to be constrained.

If the discount rate managers use to value a project depends on its idiosyncratic risk, absent any other frictions, it will lead to inefficient investment decisions from the shareholders' perspective. An additional way that shareholders can prevent this destruction in value is through increased monitoring. Furthermore, monitoring may be easier or more effective when institutions rather than households own the majority of the firm. The former have more expertise and since they typically hold larger shares, suffer less from the free-rider problem. Thus, we expect the effect to be stronger for firms with low levels of institutional ownership. Indeed, the level of insider ownership matters for the sensitivity of investment to idiosyncratic risk only when institutional ownership is low.

Finally, we are concerned that insider ownership is endogenous as it arises from an optimal contract. Thus, it is possible that the effect we are identifying comes not from insider ownership per se, but some other firm characteristic that insider ownership responds to. One such candidate is the degree of industry competition. A competitive product market will exercise higher discipline upon the manager to exert effort, and thus there may be less need to provide incentives through ownership. Moreover, as Caballero (1991) shows, the degree of product market competition can affect the relationship between investment and uncertainty. Given the degree investment irreversibility facing firms, the relationship between investment and risk should be more negative for less competitive firms. We do not find any evidence that this is the case, however. Using three different proxies for the degree of investment irreversibility, firms that operate in more ore less concentrated product 
markets display similar levels of sensitivity of investment to idiosyncratic volatility.

The rest of the paper is organized as follows. Section 1 reviews the related literature; Section 3 shows the negative relationship between idiosyncratic risk and investment; Section 4 addresses concerns about omitted variables and reverse causality; Section 5 shows how the effect varies with levels of insider ownership, convexity of executive compensation schemes and likelihood of financial constraints; Section 6 examines the interaction with institutional ownership; Section 7 examines alternative explanations; Section 8 concludes.

\section{Related literature}

On the theoretical front, the sign of the relationship between investment and total uncertainty facing a firm has been examined mostly in the real options literature. The conclusions are rather ambiguous, and the the sign of the effect of uncertainty on investment depends, among other things, on assumptions about the production function, the market structure, the shape of adjustment costs, the importance of investment lags and irreversibilities. An incomplete list includes Oi (1961), Hartman (1972), Abel (1983), Caballero (1991), Abel, Dixit, Eberly and Pindyck (1996), and Abel and Eberly (1999). While the previous papers focused on the firm's partial equilibrium problem, Angeletos (2007), Bloom (2009), Nakamura (1999) and Saltari and Ticchi (2007), among others, investigate the general equilibrium effects of an increase in uncertainty on investment and how this depends on the coefficients of risk aversion and intertemporal substitution. In most of these papers, no distinction is made between idiosyncratic and systematic uncertainty. More recently, a number of papers explore the effect of managerial risk aversion and idiosyncratic risk on the timing of investment

decisions in real option models [Hugonnier and Morellec, 2007b; Hugonnier and Morellec, 2007a; Henderson, 2007; Miao and Wang, 2007; Chen, Miao and Wang, 2009].

On the empirical front, a number of studies use the volatility of stock returns as a measure of uncertainty, and explore its effect on investment. An incomplete list includes 
Brainard, Shoven, Weiss, Cagan and Hall (1980), Leahy and Whited (1996), Henley, Carruth and Dickerson (2003), Bond and Cummins (2004), Cummins, Hassett and Oliner (2006), Bulan (2005), Bloom, Bond and Reenen (2007), and Baum, Caglayan and Talavera (2008). The conclusions of this literature is mixed both as to sign and as to the significance of the investment-uncertainty relationship, and they appear to be somewhat sensitive to the estimation method. Moreover, in most of the papers above, no theoretical distinction is made between idiosyncratic and systematic uncertainty. We complement this literature by addressing the issue that the volatility of stock returns in endogenous, which in principle depends on the firm's investment policy.

Furthermore, our paper complements the findings of Himmelberg, Hubbard and Love (2002), who document high insider ownership shares in publicly traded firms worldwide. They argue that, absent investor protection legislation, firm insiders are given endogenous ownership as a commitment device to not steal from shareholders. However, these incentives are costly, because they force insiders to bear idiosyncratic risk. They test their structural model using cross-country data, and monthly country stock returns for their measure of market-based idiosyncratic volatility. They find that countries like the US, where investor protection is high, are characterized by a lower level of insider ownership, a smaller idiosyncratic risk premium, and a steady-state capital stock closer to the no-frictions level.

\section{Model}

In this section, we propose a simple two-period model that demonstrates how idiosyncratic risk can affect capital investment in an efficient capital market, even in the absence of adjustment costs or other investment frictions. We abstract from the latter not because we think that they are not important, but because we are interested in a different channel: investment decisions are taken by managers who hold undiversified stakes, and thus are reluctant to undertake high idiosyncratic firm projects, even though the shareholders are 
perfectly diversified.

A firm starts with cash $C$ at $t=0$ and produces output at $t=1$ according to

$$
y=X \sqrt{K}+e
$$

where $e$ is managerial effort, $K$ is installed capital and $X \sim N\left(\mu, \sigma^{2}\right)$ is a shock that is specific to the firm.

The manager owns a fraction $\lambda$ of the firm, and the remaining $1-\lambda$ shares are held by shareholders who are risk averse but hold the market portfolio. We assume that, for incentives to have any bite, the manager cannot diversify his stake in the firm. The manager derives utility from consumption $\left(c_{0}, c_{1}\right)$ and disutility from effort $(e)$ :

$$
U_{0}=u\left(c_{0}\right)-v(e)+\beta E_{0} u\left(c_{1}\right)
$$

where $u(c)=-e^{-A c}, v^{\prime}>0, v^{\prime \prime}>0, v(0)=v^{\prime}(0)=0$.

The manager's contract consists of a choice of ownership $\lambda$ and an initial transfer $T$. Given the contract, the manager will choose how much to invest in capital $K$, how much effort to provide $e$ and how much to save in the riskless asset, $B$ to maximize (2), subject to (1) and the two budget constraints

$$
\begin{aligned}
& c_{0}=\lambda(C-K)-B+T \\
& c_{1}=\lambda(X \sqrt{K}+e)+R B .
\end{aligned}
$$

We assume that the principal cannot write contracts on $K, e$ or $B{ }^{1}$

Proposition 1 The manager's optimal choice of capital $K^{*}$, bonds $B^{*}$ and effort $e^{*}$ are such

\footnotetext{
${ }^{1}$ The assumption that $K$ is not contractible may seem odd at first, as in practice, capital expenditures are observable and reported by the firm. Note however, that even though investment may be observable, the amount of risk undertaken is not, and what $K$ captures here is the amount of risky investment. We could extend the model to allow two types of capital, one risky and one not. We could then allow the principal to write contracts on the total investment undertaken by the firm, but not on which capital stock was chosen. Doing so however, given that the manager can also save in the private market, would not change our results.
} 
that:

$$
\begin{aligned}
K^{*} & =\left(\frac{\mu}{2 R+\lambda A \sigma^{2}}\right)^{2} \\
R v^{\prime}\left(e^{*}\right) & =\lambda u^{\prime}\left(c_{0}\right) \\
u^{\prime}\left(c_{0}^{*}\right) & =\beta R E_{0} u^{\prime}\left(c_{1}^{*}\right) .
\end{aligned}
$$

The elasticity of investment to idiosyncratic risk equals

$$
\frac{\partial \log K}{\partial \log \sigma^{2}}=-\frac{\lambda A \sigma^{2}}{R+\frac{1}{2} \lambda A \sigma^{2}}
$$

and is decreasing in $\lambda, A$ and $\sigma^{2}$.

The first thing to note is that as long as $\lambda>0$, the manager will underinvest from the shareholders perspective. The latter are diversified and thus behave as if risk-neutral with respect to $\mathrm{X}$. Their optimal capital choice equals $K^{f b}=\left(\frac{\mu}{2 R}\right)^{2}$. In contrast, the manager holds an undiversified stake in the firm, and as such his choice of capital stock will depend on the idiosyncratic risk of the firm, $\sigma^{2}$.

If $\lambda$ were optimally chosen, it would depend, among other things, on the level of idiosyncratic risk, and the manager's risk aversion and cost of effort. The principal, by choosing $\lambda$ trades off two things: increasing $\lambda$ induces higher effort on the part of the manager, but also leads to underinvestment, since the manager is risk averse. ${ }^{2}$ In our numerical solution, we find that $\lambda$ is decreasing with the level of idiosyncratic risk and the manager's risk aversion, since in that case the costs of underinvestment is lower, and is increasing with the marginal cost of effort. ${ }^{3}$

In the following sections, we will investigate two testable implications of the model:

\footnotetext{
${ }^{2}$ This is similar to the classic incentives versus insurance tradeoff. The difference lies in the cost of providing incentives. For instance, in Holmstrom (1979) the cost of providing incentives simply the utility cost to the agent, whereas here there is an additional cost, underinvestment in capital.

${ }^{3}$ In our numerical solution we maximize total welfare with respect to $\lambda$ and $T$, subject to budget constraints and the manager's first order conditions, (5)-(7).
} 
- PREDICTION 1: Firm-level investment, even for publicly traded firms, will display a negative relationship with idiosyncratic risk.

- PREDICTION 2: The negative relationship between investment and idiosyncratic risk will be higher for firms with high levels of insider ownership.

In our empirical results we will take the variation in insider ownership as given. In reality, there are too many reasons why shares of insider ownership may vary across firms. Our concern is that $\lambda$ varies endogenously with unobservables, and the latter are responsible for the negative investment-risk relationship.

Nevertheless, we can obtain some intuition from the model regarding the effect of the endogeneity of $\lambda$. A first candidate is risk aversion. Given that we do not observe the manager's risk aversion, this will bias our results towards rejecting the second prediction, even if the model is true. For instance, suppose that $\lambda$ varies exactly inversely proportional to $A$, so that less risk averse managers are given higher insider stakes, then the investment-risk relationship will be flat along levels of insider ownership.

In Section 7.1 we will explore an alternative explanation for our findings, namely that the degree of ownership depends on the level of competition in the product market, and the latter is responsible for the observed investment-risk relationship.

\section{Investment and Idiosyncratic Risk}

In this section we examine the response of investment to the volatility of idiosyncratic risk, controlling for several factors that might affect this relationship.

\subsection{Data and Implementation}

The accounting data comes from the sample of all publicly traded firms in COMPUSTAT over the period 1970 - 2005. The data on weekly stock returns comes from CRSP over the same period. The exact details about the data construction are provided in the Appendix. 
We clean the sample by dropping firms with less than five COMPUSTAT observations, and firms in the financial (SIC code 6000 - 6999), utilities (SIC code 4900 - 4949), and government regulated industries (SIC code > 9000). We also drop firm-year observations where the investment-capital ratio is higher than 1, stock return is higher than $300 \%$, the absolute value of cashflows-over-capital is higher than 10, Tobin's $Q$ is greater than 100, book values is negative and the firm has fewer than 40 weekly observations in that year. In the end, we have an unbalanced panel of 84,907 firm-year observations.

For every firm, $i$, and every year, $t$, we construct our baseline measure of idiosyncratic volatility using weekly data on stock returns. In particular, we regress firm $i$ 's return on the value-weighted market portfolio $\left(R_{M K T}\right)$ and the corresponding value-weighted industry portfolio $\left(R_{I N D}\right)$. Our measure of yearly idiosyncratic investment volatility for firm $i$ is the volatility of the residuals across the 52 weekly observations. Thus, we decompose the total weekly return of a firm into a market-, an industry-, and a firm-specific or idiosyncratic component:

$$
R_{i, \tau}=a_{1, i}+a_{2, i} F_{i, \tau}+\varepsilon_{i, \tau}
$$

where $\tau$ indexes weeks, and where $F_{i, \tau}=R_{M K T}, R_{I N D}$. To construct $R_{I N D}$, we classify firms into 30 industries based on the Fama and French (1997) classification. Our measure of idiosyncratic risk is the volatility of the regression residuals, i.e.

$$
\sigma_{i, t}=\sqrt{\sum_{\tau \in t} \varepsilon_{i \tau}^{2}} .
$$

This decomposition is similar to Campbell, Lettau, Malkiel and Xu (2001) and does not impose any parametric structure on the evolution of the variances over time. Furthermore, even though our measure is constructed using a non-overlapping window, it is highly persistent. The pooled autocorrelation of $\sigma_{i, t}$ is 0.78 in the $1970-2005$ sample. 
We estimate the response of investment to idiosyncratic risk by:

$$
\frac{I_{i, t}}{K_{i, t-1}}=\gamma_{0}+\beta \log \left(\sigma_{i, t-1}\right)+\gamma_{1} Z_{i, t-1}+\eta_{i}+g_{t}+v_{i, t}
$$

where our baseline measure for investment is capital expenditure, $\eta_{i}$ are firm-fixed effects, $g_{t}$ are time-fixed effects ${ }^{4}$, and $Z_{i, t-1}$ is a vector of lagged variables used as controls. $Z_{i, t}$ includes : i) The logarithm of the ratio of a firm's market-to-book value, i.e. Tobin's $Q_{t}$. ii) The ratio of cashflows to capital, $C F_{t} / K_{t-1}$. iii) The logarithm of the firm's capital stock relative to the total capital stock, $\left(\hat{K}_{t-1}=K_{i, t} / \frac{1}{N_{f}} \sum_{i}^{N_{f}} K_{i, t}\right)$. iv) The firm's total stock return, $R_{t}$. v) The logarithm of the ratio of equity-to-assets, $E_{t} / A_{t}$. We include $Q$ to control for real investment opportunities, $C F / K$ to control for the well known investment-cashflow

sensitivity effect, $\hat{K}$ to ensure that we are not picking up the effect that smaller firms are more volatile yet grow faster ${ }^{5}, R$ because volatility and stock returns are positively correlated and the latter contains news about future profitability, and $E / A$ to control for the fact that highly levered firms may invest less due to debt overhang and while having more volatile equity stock returns. Table 1 provides the details about the construction of our investment and control data. Finally, the errors, $v_{i, t}$, are robust for heteroskedasticity and clustered at the firm level.

\subsection{Baseline Results}

Our estimates of Equation 11 are reported in the first three columns of Table 2 using various controls.

The coefficient on our baseline volatility measure, $\sigma_{t-1}$, varies from $-2.6 \%$ to $-4.6 \%$ and statistically significant. Given that the standard deviation of idiosyncratic volatility is 0.47 , if idiosyncratic investment volatility increases by one standard deviation, then the

\footnotetext{
${ }^{4}$ The time dummies will be suppressed in all tables that follow.

${ }^{5}$ Gala and Julio (2009) provides empirical evidence for a negative relation between firm growth and firm size. Their results can be interpreted as evidence for decreasing returns to scale. We normalize by the aggregate capital stock to ensure that $\hat{K}$ is stationary.
} 
investment-capital ratio falls by $1.2-2.2 \%^{6}$

In the fourth column of Table 2 we allow the time effects to vary by industry. This specification captures any unobservable component that varies at the industry level. Identification thus comes from differences of firms relative to their industry peers. To keep the number of fixed effects manageable, we consider 12 industries based on the Fama and French (1997) classification. Allowing the unobservable time effect to vary by industry leaves the coefficient on $\sigma_{t-1}$ mostly unaffected at $-3.7 \%$. In the fifth column of Table 2 we include lagged systematic volatility as an additional regressor, where systematic volatility is total volatility minus idiosyncratic volatility, i.e. $\sigma_{t-1}^{\text {syst }} \equiv \sqrt{\left(\sigma_{t-1}^{\text {total }}\right)^{2}-\sigma_{t-1}^{2}}$. The coefficient on systematic volatility is positive and significant, though rather small in magnitude, whereas the coefficient on our baseline idiosyncratic volatility measure is still negative and significant at $-4.5 \%$. This restricts somewhat the set of possible explanations, since most non-agency explanations for the effect of uncertainty on investment make no distinction between idiosyncratic and systematic risk. However, the two seem to predict investment in opposite directions.

Moreover, we examine whether our results are robust to allowing for lagged values of the investment rate as additional regressors, given investment is typically persistent. However, in this case, the lagged dependent variable is correlated with the unobservable firm-fixed effects, which creates a bias in the standard OLS estimators. We include the lagged investment rate and address this bias in two ways. In the sixth of column of Table 2 we replace the unobservable firm-fixed effects with industry effects at the 3-SIC digit level. In this case the coefficient on idiosyncratic volatility is at $-2.1 \%$. In the seventh column of Table 2 we use the two-step GMM estimation procedure proposed by Arellano and Bond (1991). This procedure yields consistent estimates, at the cost of imposing the restriction of noautocorrelation in the error terms. Our baseline volatility coefficient is again negative and

\footnotetext{
${ }^{6}$ We use a semi-log specification to capture the possibility, suggested by Abel and Eberly $(1996,2002)$ and Eberly (1997), that the investment- $Q$ relationship is not linear.
} 
statistically significant at $-2.4 \%$. However, the results form this column need to be taken with a measure of caution, as the Sargan test of over-identifying restrictions rejects the null of valid instruments. ${ }^{7}$

Finally, we examine whether $R \& D$ investment responds in a similar way to idiosyncratic risk as capital investment. Investment in $R \& D$ is subject to different physical frictions than investment in physical capital, yet it is still subject to the same agency cost. Managers may be reluctant to invest in risky $\mathrm{R} \& \mathrm{D}$ projects, even if the risk is idiosyncratic to the firm, if they end up bearing some of this risk. As can be seen in the last column of Table 2, the coefficient of $R \& D$ investment on idiosyncratic risk is -0.045 and statistically significant at the $1 \%$ level.

\subsection{Sources versus Uses}

In this section we examine which parts of the firm's balance sheet adjust when an increase in uncertainty leads to a fall in investment. Due to an accounting identity, a reduction in uses must be accompanied by either an increase in other uses of funds or a reduction in sources. ${ }^{8}$ The uses of a firm's funds include investment in capital expenditure, acquisitions, dividend payouts, purchase of stock, and changes in cash-holdings. The sources of a firm's funds are asset sales, equity issuance, changes in short-term debt, and changes in long-term debt. The definitions of the variables are in Table 1 .

We repeat our baseline specification 11, with the dependent variable each time being each one of the sources and each one of the uses of the firm's funds. We also do this with current cashflows added in the regressor set. Next, we use SUR to estimate the system of baseline specifications for each source variable and each use variable with the cross-equation constraint that $\Delta($ Sources $)=\Delta($ Uses $)$. We do the same for the case where we add current

\footnotetext{
${ }^{7}$ This specification includes the standard measure of Tobin's $Q$ both as a regressor, and as part of the instrument set. The problems with this approach have been demonstrated in Cummins et al. (2006).

${ }^{8}$ The fact that investment and financing decisions are interconnected by accounting identities has been recognized by Gatchev, Pulvino and Tarhan (2008)
} 
cashflows as an additional regresor. The coefficients for the effect of idiosyncratic risk on each one of the dependent variables are presented in Table 3. Here $C N$ indicates whether the constraint has been imposed, and $C F 1$ indicates whether current cashflows has been included as a regressor. Across specifications, we see that an increase in idiosyncratic risk causes a fall in capital-expenditure investment; a fall in a fall in dividend payout and stock repurchases; and an increase in the cash held within the firm.

Our findings complement Ridick and Whited (2008), who show that firms with more uncertainty have a higher marginal propensity to save from their operating income. We find that, consistent with a precautionary savings behavior by managers, controlling for the level of operating income, an increase in (idiosyncratic) uncertainty leads to a reduction in investment and shareholder payout and an increase in holdings of liquid securities.

\section{Omitted Variable Bias and Endogeneity}

So far we have documented a robust negative relationship between idiosyncratic risk and the investment of publicly traded firms. Interpreting our findings as evidence of a causal relationship can be somewhat problematic however, because of an omitted variables problem and an endogeneity bias. As stressed by Berk, Green and Naik (1999) and others, the value of a firm can be decomposed as the value of existing assets and the value of growth opportunities. The volatility of stock returns will be a weighted average of the volatility of each component. Furthermore, as options are levered claims on the firm, most real option models predict that the volatility of the growth options is greater than the volatility of assets in place.

Therefore, a firm exhibiting high volatility of stock returns, idiosyncratic or systematic, could simply be a firm with high growth opportunities. Failure to properly account for the latter, for instance if $Q$ is mismeasured, leads to an omitted variable bias. This is likely to bias our estimates upwards, as long as idiosyncratic volatility and growth opportunities are 
positively correlated.

Furthermore, investment decisions affect the mix between growth options and assets in place. For instance, consider a situation where the firm has committed to invest in the future in a certain project. This decision has transformed a growth option (the unrealized project) to an asset that will be productive in the future. By altering the asset mix, this decision affects the volatility of stock returns today. If the idiosyncratic volatility of growth options is greater than that of assets in place, the decision to invest in the future will lower the volatility of stock returns. This will bias our estimates towards a negative relationship, but the causality would go the other way.

In this section we will try to alleviate these concerns. We deal with the omitted variable bias by using alternative measures of growth opportunities and by allowing for measurement error in $Q$ in the estimation. We deal with the endogeneity problem by instrumenting for idiosyncratic volatility.

\subsection{Alternative Measures of Growth}

Our first alternative measure of growth opportunities is based on Bond and Cummins (2004) and Cummins et al. (2006), who construct a measure of Tobin's $Q$ from I/B/E/S data on analysts' earnings forecasts. The I/B/E/S data set starts in 1982, and contains analysts' one- and two-year ahead earnings forecasts for each firm, the mean of the analysts' forecasts issued for each firm (consensus forecast), and a forecast of long-term earnings growth for each firm.

We follow Cummins et al. (2006) in constructing our alternative measure for $Q$, denoted by $Q^{i b e s}$, for each firm $i$ and each year $t$ :

$Q^{i b e s}=\beta E C F_{i t}+\beta^{2}(1-\delta) E C F_{i, t+1}+\frac{1}{2}\left(E C F_{i, t}+E C F_{i, t+1}\right) \sum_{k=3}^{n}\left[\beta^{k}(1-\delta)^{k-1}\left(1+E G R_{i t}\right)^{k-2}\right]$ where $E C F_{i t}$ and $E C F_{i, t+1}$ are the consensus forecast for the firm's expected net income in periods $t$ and $t+1$, respectively, scaled by the replacement value of the capital stock at the 
beginning of period $t, E G R_{i t}$ is the firm's expected growth rate of net income in the following periods, $\beta$ is the discount factor set at $0.91, \delta$ is the depreciation rate set at $=0.15$, and $n$ is the number of years set at $10^{9}$. In other words, this measure of investment opportunities uses as proxy for the unobserved future marginal products of capital an approximation for the future average products based on I/B/E/S earnings forecasts. The sample ranges from $1982-2005$ and contains 25,433 firm-year observations.

We then estimate Equation 11 via OLS adding $Q_{t}^{\text {ibes }}$ to the list of controls, $Z_{t}$. The results are presented in the first two columns of Table 4 . In the first column, only $Q^{i b e s}$ is used as the measure of growth opportunities, whereas in the second column we include both $Q^{i b e s}$ and the market-based proxy for Tobin's $Q$. The coefficient on $\sigma$ is statistically significant and equal to $-2.1 \%$ and $-1.8 \%$ respectively. Results are similar, though we do not report them, when we control for lagged investment and use the ? estimator, although as before, the $J$ test rejects the null of valid instruments.

Our second alternative measure of growth opportunities is based on Kogan and Papanikolaou (2009) and is the beta of a regression of a firm's stock return on a proxy for investment-specific shocks, namely a portfolio long the investment-producing sector and short the consumption-producing sector $(I M C)$. Their measure is derived based on a structural model, and the intuition is that firms with more growth opportunities are more likely to benefit from a positive investment shock, defined as a reduction in the cost of new capital. In their model, the investment-shock beta, $\beta^{i m c}$ is a linear function of the weight of growth opportunities to total firm value.

We follow Kogan and Papanikolaou (2009) and construct $\beta_{i t}^{i m c}$ by estimating, using weekly returns within year $t$, the univariate beta of firm i's log stock return with returns on the $I M C$ portfolio. The construction is similar to our idiosyncratic volatility measure in Equation 9. Since in their model, $\beta^{i m c}$ measures growth opportunities for firms producing the final consumption good, whereas the investment sector is modeled in reduced form, we drop

\footnotetext{
${ }^{9}$ Cummins et al. (2006) find that their results are robust to alternative parameter values and time horizons.
} 
the capital-producing firms from the sample, leaving us with a sample of 60,622 firm-year observations.

The third and fourth columns of Table 4 show results of estimating Equation 11 and adding $\beta^{i m c}$ to the list of controls, with and without the market based measure of Tobin's $Q$. In both cases, the coefficient on $\sigma$ is still statistically significant and equal to $-4.7 \%$ and $-3.6 \%$ respectively.

\subsection{Measurement Error in Tobin's $Q$}

In this section, rather than considering alternative measures of growth opportunities, we deal with the measurement error in Tobin's $Q$ directly in estimation. We follow the approach of Erickson and Whited (2000, 2002), and Bakke and Whited (2007), who use a higher-order GMM estimation method to correct for measurement error in $Q$. Their estimation method exploits the non-normality of Tobin's $Q$, so in this section we replace $\log Q$ with $Q$ in the set of controls.

Before the data is used for estimation, it needs to pass an identification test in each crosssection. The model is identified as long as the 'true' Tobin's $Q$ is non-normally distributed. Our sample passes the identification test in 16 out of the 36 cross-sections, based on individual p-values. Given that the smallest p-value is less than $0.2 \%$, the Bonferroni test rejects the null of no identification in the entire sample with a p-value of $36 \times 0.2 \%=7.2 \% .{ }^{10}$

We report the results of estimating Equation 11 using the third-order moment estimator in the sixth column of Table 4 . The fifth column presents the corresponding OLS estimates when $\log Q$ is replaced with $Q$ in the set of controls for comparison purposes. We report the time-series average of the coefficient in each cross-section and estimate the standard errors via the Fama and MacBeth (1973) procedure. Using the Erickson and Whited (2000)

\footnotetext{
${ }^{10}$ The Bonferroni test is a conservative upper bound for the p-value of the joint test. Suppose that we run two tests and reject if either $\mathrm{A}$ or $\mathrm{B}$ occurs. Each has probability $\mathrm{p}$ of rejecting under the null. The overall probability of rejecting is $P(A \cup B)=P(A)+P(B)-P(A \cap B) \leq 2 p$. Note that this test makes no assumption that $A$ and $B$ are independent.
} 
estimator, the coefficient on idiosyncratic volatility is $-4.6 \%$, which is very close to the OLS estimate of $-4.5 \%$ in column five.

Based on the $\tau^{2}$ statistic, the empirical proxy for Tobin's $Q$, i.e. the usual accounting measure of book-to-market, explains $32 \%$ of the variation in the true measure of investment opportunities, which is comparable to the findings of Erickson and Whited $(2000,2002)$, Bakke and Whited (2007), and Hennessy (2004).

\subsection{Reverse Causality}

Ideally, we would like to establish a causal link from higher idiosyncratic volatility to lower investment. However, our measure of volatility is based on stock returns, which are endogenous and incorporate information about past and, more importantly, future investment behavior, to the extent that the latter has been decided already. Our concern is then that causality goes from investment to returns. To see this more clearly, consider an anticipated increase in future investment. To the extent that this represents a commitment on the firm's part, it will have the effect of transforming growth options, since they are being exercised, into productive assets. Most real option models predict that the riskiness of the former is greater than the riskiness of the latter. Thus, the act of investment has reduced the overall risk of the firm, which is the sum of the existing assets and growth parts.

To formally address the possibility that idiosyncratic volatility responds negatively to anticipated future increases in investment, we instrument for idiosyncratic volatility with a measure of a firm's customer base concentration. The idea is that, if a firm's customer base is very concentrated, the firm will be more sensitive to shocks affecting other firms, and hence its own idiosyncratic risk will be higher. If, instead, the customer base is well diversified, the firm will be more insulated from shocks coming from other firms. Our identification assumption is that the concentration of a firm's customer base does not react to future investment policies. However, the concentration of a firm's customer base may be a function of the number of customers the firm has, i.e. the level of sales. This may depend on 
anticipated investment behavior, we add the level of sales (normalized by capital) as an additional control.

We construct a measure of the concentration of a firm's sales using data from the COMPUSTAT segment files. Regulation SFAS No. 131 requires firms to report information about operating segments in interim financial reports issued to shareholders. In particular, firms are required to disclose the amount of sales to and the identity of any customer representing more than $10 \%$ of the firm's total reported sales. Our measure of sales concentration is:

$$
H_{i, t}=\sum_{p}\left(\frac{\text { sales }_{p, i, t}}{\text { sales }_{i, t}}\right)^{2}
$$

where sales $_{p, i, t}$ represents the reported sales of firm $i$ to customer $p$ at time $t$, and sales $_{i, t}$ represents the total sales of firm $i$ at time $t .^{11}$

Subsequently, we use $H_{i, t}$ as an instrument for idiosyncratic volatility. Table 5 presents our results using $2 S L S$, where the standard errors are heteroskedasticity-robust and clustered at the firm-level. Because our instrument does not vary a lot over time, we have dropped firm-fixed effects from the estimation. Instead, we add industry-fixed effects and, to partially account for the presence of unobservable persistent components at the firm level, we include the lagged value of the investment rate in the regressors. Since $H_{i, t}$ does not vary a lot over time, our identification comes mostly from the cross-sectional rather than the time-series dimension of our panel.

The left panel of Table 5 shows the first-stage results, that is the regression of $\sigma$ on $H$ and controls. The $t$ statistic on $H_{i, t}$ is 5.24 , suggesting that the instrument is not weak. In the right panel of Table 5 we show the results of the second stage, along with the results using OLS for the same sample and specification for comparison purposes. The coefficient on idiosyncratic volatility is statistically significant and equal to -0.15 in the 2SLS case versus

\footnotetext{
${ }^{11}$ We normalize $H$ by the total sales of the firm, i.e. COMPUSTAT item 12 rather than $\sum_{p}$ sales $s_{p, i, t}$ because we are interested in the concentration of an entire firm's customer base, rather than within the set of large customers. Our measure effectively replaces the sales of customers who represent less than $10 \%$ with zero.
} 
-0.025 in the OLS case. We also report values of the Kleibergen and Paap (2006) test for the null of weak instruments in the presence on non-iid errors. The critical values for this test are from Stock and Yogo (2002) under the requirement that the maximal bias of the IV estimator relative to OLS is $5 \%$. Based on these values, the test rejects the null of weak instruments.

\section{Risk Aversion}

In section 4 we concluded that the effect of idiosyncratic risk on investment does not operate through the firm's real investment opportunities, at least as perceived by outside investors. Nevertheless, idiosyncratic risk may still affect investment if it affects the valuation of investment opportunities by the agents who make the investment decisions. In other words, the effect is operating through a channel of effective managerial risk aversion, where the decision makers are reluctant to undertake projects with high idiosyncratic risk because it leads to an increase in the variability of the firm's cashflows. Managers will care about this idiosyncratic variability, even though outside investors do not, because of the firm's compensation scheme or because the firm faces convex costs of external finance.

In this context, we examine a number of predictions. The first starts from the premise that managers hold a significant fraction of their firm's stock for incentive reasons. These managers are then, in all likelihood, poorly diversified ${ }^{12}$, and, if they are risk averse, then the volatility of idiosyncratic risk directly affects their valuation of the firm's investment opportunities. Thus, we expect the negative effect of idiosyncratic risk on investment to be stronger for firms that have high levels of insider ownership.

Second, over the last twenty years, a number of firms have switched to option-based compensation. Compensating executives with options, rather than shares, provides managers

\footnotetext{
${ }^{12}$ Although we do not have data on the entire portfolio allocation of managers, it is unlikely that they are well diversified, given the evidence on limited stock-market participation, and infrequent portfolio adjustment for stock-market participants. See, for example, [Vissing-Jørgensen, 2002], and Curcuru, Heaton, Lucas and Moore (2004).
} 
with a convex payoff, whose value increases in the volatility of the underlying. Thus, all else equal, increasing the convexity of the compensation package will tend to mitigate the effect of risk aversion. ${ }^{13}$ We will test this prediction by examining the investment-risk sensitivity for firms with different levels of convexity in their compensation schemes. We expect that the negative effect of idiosyncratic risk on investment to be smaller for firms with more convex compensation schemes.

Third, we expect the effect to be stronger for firms that are more likely to be financially constrained. Our definition of the latter is firms that have good investment opportunities but need to raise external funds to undertake them. Froot et al. (1993) show that convex costs of external finance may induce firms to behave in a risk-averse fashion, even if the decision makers are risk-neutral. This introduces a motive for managers to avoid excessive risk-taking, even if that risk is idiosyncratic. Thus, we treat the likelihood of financial constraints as increasing the effective risk aversion of the decision makers.

\subsection{Managerial Ownership and Risk Aversion}

In this section we examine the sensitivity of the idiosyncratic uncertainty-investment relationship to ownership by insider managers. We expect that investment will be more sensitive to idiosyncratic risk in firms where the managers hold a larger fraction of the firm's shares.

Our first source of managerial ownership data is the Thomson Financial database of filings derived from Forms 3, 4,5, over the period 1986-2005. We take as measure of insider ownership in year $t$ the reported shares held by a group of insiders at the end of the year or at the latest filing date, as a fraction of the shares outstanding in the firm. We drop missing and zero ownership values. To construct our firm-level measure of insider ownership, we group together the yearly holdings of a firm's shares by all of the firm's officers ${ }^{14}$. This sample consists of 35, 336 firm-year observations.

\footnotetext{
${ }^{13}$ See Ross (2004) for a formal treatment.

${ }^{14}$ We include the following role classifications: O, OD, OE, OB, OP, OS, OT, OX, CEO, CFO, CI, CO, CT, H, GM, M, MD, P, EVP, VP, SVP.
} 
Table 6 presents some summary statistics for firms with different levels of insider ownership. We report time series averages of the median characteristic within ownership quintiles. The median level of insider ownership across the five groups varies from $0.1 \%$ to $16.2 \%$, which is quite substantial. The firms with high levels of insider ownership tend to invest more on average, have lower ratios of physical capital to book assets, have lower leverage and lower market capitalization. In addition, they tend to have higher levels of idiosyncratic risk, pay less dividends and hold more cash.

Table 7 presents the estimation results. Every year, we sort firms into quintiles, based on lagged values of insider officer stock ownership. The difference in the sensitivity of investment to idiosyncratic risk between the first and the fifth quintile coefficients ranges from -0.021 to -0.024 depending on controls, and is statistically significant at the 5 and $10 \%$ level respectively.

We perform a number of robustness checks, but to conserve space we only report a brief summary of the results. First, we use several alternative measures of insider ownership. Our first alternative measure focuses only on the firm's CEO's and CFO's. This corresponds to the most narrow definition of an insider, since it only includes the insiders who are most likely to be making investment decisions. In this smaller sample, the difference in sensitivity of idiosyncratic risk to investment across quintiles ranges from -0.021 to -0.027 , depending on controls, and is significant at the $10 \%$ level. Our second alternative measure uses the COMPUSTAT Execucomp database, which is available over the period $1992-2005$. In this sample, the difference in the sensitivity of idiosyncratic risk for between the top and bottom ownership quintiles ranges from -0.024 and -0.037 , depending on controls, and is statistically significant at the $10 \%$ level.

Furthermore, as we argued above, biases due to omitted variables or endogeneity could bias our OLS coefficients. We estimate the above relationships using instrumental variables, as described in Section 4.3. We estimate the first-stage regression over the entire sample, and estimate the second stage within ownership quintiles as above. Using IV, the difference in the 
sensitivity of idiosyncratic risk between the top and bottom ownership quintiles ranges from -0.028 and -0.029 , depending on controls, and the former only is statistically significant at the $10 \%$ level.

Finally, Table 6 shows that there is a systematic relationship between the level of insider ownership and market capitalization. We explore whether the investment-risk relationship varies across quintiles of market capitalization. The difference in investment-risk sensitivities between firms in the smallest and the largest quintile ranges equals -0.01 and is not statistically significant. The full set of results is reported in the web appendix, available from the authors' websites.

\subsection{Option-based Compensation}

The previous section focused on ownership by insiders in the form of shares in the firm, which exposes the manager to both profits and losses. An alternative form of ownership could involve the manager owning options on the firm's shares. If the executive holds a call option, he receives a payoff $V=\max (S-X, 0)$, that is he receives $S-X$ as long as the stock price $(\mathrm{S})$ exceeds the exercise price $(\mathrm{X})$, and zero otherwise. The exercise price is a feature of the contract and is usually set to be equal to the stock price at the time of the option grant. Due to the convex shape of the payoff function, which allows the executive to participate in gains but not in losses, an executive who is mostly compensated with options rather than shares will be effectively less risk averse, and in fact he may be even risk loving in some regions. Consequently, we expect that firms who grant their executives more convex compensation schemes and protect them from losses should exhibit investment behavior that is less sensitive to the level of idiosyncratic volatility.

We use data on CEO option grants from Execucomp and compute the partial derivatives with respect to stock return volatility and stock price of the BlackScholes option-pricing model as adjusted for dividends by Merton (1973). In order to compute the Black Scholes sensitivities, we need estimates of the time-to-maturity and exercise price for all options. 
Execucomp provides this information for new option grants, but not for existing options. Thus, we use the Core and Guay (2002) procedure to derive approximate estimates of these sensitivities. Core and Guay provide an approximation technique that relies only on data from one proxy statement. Their procedure approximates the average strike price using information on the number and current realizable value of exercisable and unexercisable options held by each executive. Dividing the unexercisable (excluding new grants) and exercisable realizable values by their respective numbers held by the executive, respectively, yields estimates of, on average, $S-X$. Subtracting these average profits per option from the firms stock price generates an estimate of the average exercise price $(\mathrm{X})$ of the executives unexercisable and exercisable options. They estimate the maturity as one year less than the maturity of new options for unexercisable options and four years less for exercisable options. Core and Guay provide evidence that their procedure produces measures of sensitivities that are very highly correlated with values calculated using the complete time series of proxy statements. Our sample contains data from 1992 - 2005 and contains 13, 354 observations.

For a given option scheme, the two variables of interest there will be $N_{o} \times$ vega and $N_{o} \times$ delta. The first measures the change in the executive compensation scheme per unit increase in idiosyncratic volatility, where $N_{o}$ is the number of options granted. The second measures the change in the executive compensation scheme per unit increase in the underlying stock price. Since one single share has $\delta=1$, endowing the manager with $N_{o}$ options with a delta $=\delta$ is equivalent, in terms of stock price exposure, to endowing him with $N_{o} \times \delta$ units of stock. The two contracts will not have the same exposure to volatility however: the first will have a volatility exposure equal to $N_{o} \times v e g a$, whereas the second will not as it is a linear contract.

We construct firm-level measures of convexity and level exposure by aggregating across executives in Execucomp.

$$
\overline{V E G A}_{i, t}=\sum_{j} \sum_{s} \frac{1}{E_{i, t}} N_{j, i, s, t} v e g a_{j, i, s, t}
$$


and

$$
\overline{\operatorname{DELTA}}_{i, t}=\sum_{j} \sum_{s} N_{j, i, s, t} \operatorname{delta}_{j, i, s, t},
$$

where $N_{j, i, s, t}$ refers to the options of type s granted to executive $\mathrm{j}$ in firm i at time t, $E_{i, t}$ refers to the number of executives in firm i at time $\mathrm{t}$, and $v e g a_{j, i, s, t}$ and $\operatorname{delta}_{j, i, s, t}$ refer to the sensitivities of option s granted to executive $\mathrm{j}$ in firm $\mathrm{i}$ at time $\mathrm{t}$ with respect to volatility and stock price respectively.

We first investigate the unconditional effect of convexity on the sensitivity of firm-level investment to idiosyncratic volatility. As before, we sort firms every year into 5 quintiles, based on the total sensitivity of their executive compensation package to volatility. The results are shown in Table 8. Consistent with our expectation, the pattern of the coefficient on idiosyncratic volatility is declining in $\overline{V E G A}_{i, t}$. Firms where executives benefit more from increases in volatility display investment behavior that is less sensitive to idiosyncratic volatility. The difference in the sensitivity of idiosyncratic risk between the top and bottom quintiles ranges from 0.069 to 0.028 , depending on controls, and is statistically significant at the 1 and $10 \%$ level respectively. As a robustness check, we also estimate the above relationship using IV, instrumenting for volatility with our sales concentration measure. The difference in sensitivity of investment to idiosyncratic risk ranges from 0.01 to 0.11 , depending on controls, and the latter only is significant at the $1 \%$ level.

However, Ross (2004) shows that simply granting an executive more call options does not necessarily make him less risk averse. The reason is that there is an offsetting effect coming from the option's delta, or it's sensitivity to stock price changes. Thus, to investigate the effect of increased convexity in executive compensation schemes it is necessary to control for the level of ownership. First we adjust the ownership measures constructed in Section 5.1 for executive's exposure through options. We add to the number of shares held by executive $\mathrm{j}$ and amount equal to $\sum_{s} N_{j, i, s, t}$ delta $a_{j, i, s, t}$. Every year, we sort all firms into terciles based on insider ownership. Within each ownership tercile, we sort firms into terciles based on 
$\overline{V E G A}_{i, t}$. We report results for our measure of insider ownership with and without adjusting the insider ownership data for options held by executives separately in Table $9{ }^{15}$ Controlling for the level of insider ownership, the difference in the sensitivity of idiosyncratic risk to investment ranges from 0.049 to 0.084 , depending on controls and ownership terciles and is always significant at the $5 \%$ level.

Our results in this section complement the findings of Knopf, Nam and Jr. (2002), who find that managers are more likely to use derivatives to hedge when the sensitivity of their stock and stock option portfolios to stock price is higher and the sensitivity of their option portfolios to stock return volatility is lower.

\subsection{Financial Constraints}

In this section we explore how the sensitivity of investment to idiosyncratic risk varies across firms that differ in their likelihood of being constrained. We expect that investment will be more sensitive to idiosyncratic risk in firms that are more financially constrained. Our intuition follows from Froot et al. (1993), who argue that in the presence of convex costs of external finance, risk neutral managers have a precautionary savings motive, and thus may underinvest in high idiosyncratic risk projects.

We consider two proxies for the likelihood of a firm facing financial constraints. The first is based on Whited and $\mathrm{Wu}$ (2006) and the second is based on whether the firm has debt rated by Standard and Poor's. The latter measure assumes that firms with a credit rating have access to the public debt markets, and as such are less likely to be financially constrained.

We obtain the data on credit ratings from Compustat. We split the universe of firms into two unequal groups, depending on whether the firm has been assigned a long-term credit rating, and treat the ones with a credit rating as less likely to be financially constrained.

\footnotetext{
${ }^{15}$ For each firm, we add to the number of shares held by insiders $\overline{D E L T A}_{i, t}$ to compute the total effective number of shares.
} 
The left panel of Table 10 classifies the firms into quintiles every year, based on lagged values of the Whited-Wu index of financial constraints, where a higher value for the index indicates that the firm is more likely to be financially constrained. The difference in the sensitivity of idiosyncratic risk to investment ranges from -0.014 to -0.038 , depending on controls, and is significant at the $5 \%$ and $1 \%$ level respectively. In the right panel of Table 10 we report results for firms with and without an S\&P credit rating. We find that investment is more sensitive to idiosyncratic risk for firms without a bond rating, and the difference in coefficients ranges from -0.010 to -0.016 , depending on controls, and is significant at the $5 \%$ and $1 \%$ level respectively.

Finally, we estimate the above relationships using instrumental variables, as described in Section 4.3. We estimate the first-stage regression over the entire sample, and estimate the second stage within ownership quintiles as above. Using IV, the difference in the sensitivity of idiosyncratic risk between the top and bottom quintiles for the WW index ranges from 0.0126 and 0.0634 , depending on controls, and the latter difference is statistically significant at the $1 \%$ level. Using IV, the difference in investment-risk sensitivities for firms without and with a credit rating ranges from 0.015 and 0.037 , depending on controls, and the latter is significant at the $1 \%$ level. To conserve space we omit the full set of results, but they are available in the web appendix, available from the authors' websites.

Overall, the results of this section are somewhat ambiguous since they depend on the estimation method and measure of financial constraints. We interpret the results as mixed evidence that the investment-risk sensitivity is stronger for financially constrained firms.

\section{Managerial Risk Aversion and Corporate Governance}

So far, our evidence suggests that idiosyncratic risk affects the investment of publicly traded firms likely due to managerial risk aversion or the presence of financial constraints. In the latter case, managerial and shareholder objectives are aligned, but not in the former. 
If managers turn down high idiosyncratic risk but positive NPV projects because they are poorly diversified, this will reduce shareholder value. Shareholders may take steps to mitigate this loss in value, possibly by monitoring managerial investment decisions. Monitoring and incentives are substitutes, each with their own strengths and weaknesses. Even though a formal model is outside the scope of this paper, we expect that firm-level investment will be less sensitive to risk in firms where monitoring is more effective.

We proxy for the quality of monitoring by the fraction of a firm's shares held by large institutional investors. The data on institutional ownership comes from the Thomson Financial database derived from $13 F$ filings, over the period $1981-2005 .{ }^{16}$ For each firm appearing in the $13 F$ filings, we define institutional ownership as the fraction of the firm's stock that is owned by all institutional investors. For each firm/stock and for each quarter, we sum the holdings of all reporting institutions and we divide by the total shares outstanding for the firm. We then use the unique firm identifiers to merge the firms from the $13 F$ filings with our sample of the COMPUSTAT firms. We drop missing and zero ownership values. We follow Nagel (2005) in adjusting institutional data for stock splits. In the end, we are left with 34, 862 firm-year observations.

As before, every year, we sort firms on terciles based on their level of institutional ownership. Within each tercile, we sort firms into ownership terciles. We report results with and without adjusting the insider ownership data for option holdings. We show the results in Table 11. Investment is the most sensitive to risk when monitoring is low and insider managerial ownership is high. For firms with low institutional ownership, the difference in investment-idiosyncratic risk sensitivities between the high and low terciles ranges from -0.025 to -0.060 , depending on controls and whether insider ownership is adjusted for op-

\footnotetext{
${ }^{16}$ A 1978 amendment to the Securities and Exchange Act of 1934 required all institutions with more than 100 million dollars of securities under discretionary management to report their holdings to the Securities and Exchange Commission (SEC). In particular, all common stock positions over 10, 000 shares or over 200, 000 dollars must be disclosed quarterly, by filing form $13 F$. In cases where investment discretion is shared by more than one institution, care is taken to prevent double-counting. Filing institutions may belong to one of five categories: bank, insurance company, investment company (mutual fund), investment advisor (brokerage firm), and other (pension fund, university endowment).
} 
tion holdings. In three out of the four cases, the difference is statistically significant at the $10 \%$ level. In contrast, for firms with high institutional ownership, the difference in coefficients ranges from 0.007 to -0.010 and is not statistically significant.

\section{Alternative Explanations}

In this section, we explore two alternative explanations for our results that do not rely on managerial risk aversion. The first alternative explanation that we consider is that the mechanism that drives the investment-idiosyncratic risk sensitivity is product market competition, and insider ownership arises as an endogenous response to the firm's competitive environment. The second alternative mechanism operates through the credit channel, in that high idiosyncratic risk firms may face higher costs of borrowing, which may lead to lower investment.

\subsection{Product Market Competition}

Our first concern is that what we are really capturing is that that the sensitivity of investment to idiosyncratic risk is more negative for firms in less competitive industries, and in those firms the need to provide managerial incentives is greater, and thus the higher levels of insider ownership. Regarding the effect of product competition, Caballero (1991) considers a model with investment frictions and imperfect competition. He shows that, given the degree investment irreversibility facing the firms, the relationship between investment and uncertainty should be more negative for less competitive firms. The intuition is that if a firm has a lot of market power, then it is more likely to exert downward pressure on the price by investing and increasing output. ${ }^{17}$ In addition, a number of theoretical papers examine the

\footnotetext{
${ }^{17}$ Models of irreversible investment under perfect competition and constant returns to scale predict a negative relationship between uncertainty and the timing of investment: when the investment decision cannot be reversed, then an increase in uncertainty increases the benefit of waiting to invest, and hence firms will invest only when the asset value exceeds the investment cost by a (potentially large) option premium [Caballero, 1991; Abel, 1983; Hartman, 1972; Abel et al., 1996]. But if an increase in uncertainty leads to delaying investment, compared to the previous periods, this will also register as a fall in the level
} 
effect of product market competition on managerial incentives [Hart, 1983; Scharfstein, 1988; Schmidt, 1997; Raith, 2003]. While the conclusion is somewhat ambiguous, product market competition can exert a disciplining effect on managers, and could thus act as a substitute for incentive schemes.

We test the prediction of Caballero (1991), namely is that the relationship between investment and uncertainty should be more negative for less competitive firms, given the degree investment irreversibility facing the firms. We use the Herfindahl concentration index to capture the degree of product market competition in the industry, where we define industries at the 3-digit SIC level. We use three alternative measures to capture the degree of investment irreversibility in a given firm. The first is rental expenditure: investment is less irreversible, when firms rent rather than own capital. To avoid size effects, we normalize rental expenditures by the capital stock. The second is capital depreciation: investment is less irreversible when capital depreciates faster. We measure capital depreciation at the 3-digit SIC industry level. Our third measure is based on Shleifer and Vishny (1992), and is the beta of a firm with its corresponding industry. Firms that are highly correlated with their industry peers have more difficulty disinvesting following a bad shock, since the rest of the industry which is the natural buyers of this capital are also likely to have suffered a negative shock. We estimate the firm's sensitivity to its corresponding industry portfolio from Equation 9.

Every year, we sort firms into terciles first on our three measures of investment irreversibility and then on the degree of industry concentration. We present the results in 12 . The difference in the investment-uncertainty sensitivity between firms in more versus less concentrated industries ranges from -0.024 to 0.037 , depending on the measure and level of irreversibility, and whether additional controls are included. The coefficient is negative

of investment. Moreover, Caballero (1991) shows that, when the assumptions of perfect competition and constant returns to scale are relaxed, then uncertainty has direct implications about the level of investment, since the determination of what is a "good" shock or a "bad" shock in the future depends on current investment: the less the firm invests in the current period, the more likely it is to get a good shock in the future, i.e. a shock for which the capital in place is less than the desired capital stock. 
and statistically significant only in one out of the twelve cases. It appears then that product market competition is unlikely to be the driving force behind our results.

\subsection{Credit Channel}

The second alternative explanation that we consider operates through the lending channel. An increase in idiosyncratic risk may lead to an increase in the probability of default. This may adversely affect investment in a number of ways. the first possibility could be an increase in the cost of borrowing, or equivalently on the severity of the financial constraint. Alternatively, if there are deadweight costs of bankruptcy, shareholders may be unwilling to increase the scale of the firm when the likelihood of default increases.

In addition, we expect to see that the relationship between investment and probability of default to be more negative for financially constrained firms. If the level of insider ownership is correlated with the level of financial constraints, in that it proxies for the inability to persuade outside investors to finance the firm, then we may find that the investment-risk relationship is stronger for firms with higher levels of insider ownership, even though the mechanism is quite different.

We address this concern in a number of ways. First, Table (3) shows that a firm's long-term debt does not show a statistically significant decrease following an increase in idiosyncratic risk. This goes somewhat against a credit rationing story, since the drop in investment is not accompanied by a drop in debt.

Second, we restrict the sample to firms with a credit rating, which are firms unlikely to be financially constrained given that they have access to public debt markets. We repeat the sort based on insider ownership. The difference in coefficients between the high and low ownership terciles ranges from -0.019 to -0.038 depending on controls and is statistically significant at the $10 \%$ and $1 \%$ level respectively. The full set of results is reported in our Web Appendix. 


\section{Conclusion}

In this paper we provide evidence for a robust negative, and in all likelihood causal, relationship between idiosyncratic risk and investment for publicly traded firms in the United States. We find evidence that this negative effect is due to risk aversion, resulting from poor managerial diversification or from financial constraints. Also, we find evidence that the effect is weaker in firms with more convex compensation schemes. Finally, the effect is stronger in firms where the quality of monitoring is low and, at the same time, the manger holds a higher fraction of the firm's shares.

It has by now been widely empirically documented that in the US private entrepreneurs hold a poorly diversified portfolio, with most of their wealth invested in the single firm they own, and that therefore the degree of entrepreneurial risk aversion is crucial for the entrepreneurial investment decision [Heaton and Lucas, 2000b; Heaton and Lucas, 2000a; Vissing-Jørgensen, 2002; Moskowitz and Vissing-Jørgensen, 2002]. Our results indicate that there might be important similarities in the investment decision-making process between privately held and publicly traded businesses, since these decisions are made by poorly diversified executives, rather than well-diversified shareholders.

Our results also provide a justification for granting options to executives rather than shares to preserve incentives while mitigating their risk aversion. Even though executives are undiversified, a compensation scheme that provides some measure of downside protection could serve to better align management and shareholder incentives, at least regarding the effect of diversifiable risk on the investment decision. Alternatively, strong shareholders could effectively monitor these decisions.

In addition, the implications of fiscal policy in such an environment might turn out to be different than usually anticipated. For instance, Panousi (2008) finds that capital-income taxation may actually stimulate capital accumulation in a model where all agents are private entrepreneurs facing only undiversifiable investment risk. Put differently, examining the role 
of insurance provision, either by the government or by private markets, for the agents who take investment decisions becomes even more important once one recognizes that publicly traded firms are subject to the similar considerations as privately held businesses. 


\section{References}

Abel, A. B. (1983). Optimal investment under uncertainty, The American Economic Review 73(1): 228-233.

Abel, A. B., Dixit, A., Eberly, J. C. and Pindyck, R. S. (1996). Options, the value of capital, and investment, The Quarterly Journal of Economics 111(3): 753-77.

Abel, A. B. and Eberly, J. C. (1999). The effects of irreversibility and uncertainty on capital accumulation, Journal of Monetary Economics 44(3): 339 - 377.

Angeletos, G. M. (2007). Uninsured idiosyncratic investment risk and aggregate saving, Review of Economic Dynamics 10(1): 1-30.

Arellano, M. and Bond, S. (1991). Some tests of specification for panel data: Monte carlo evidence and an application to employment equations, Review of Economic Studies 58(2): 277-97.

Bakke, T.-E. and Whited, T. M. (2007). Which firms follow the market? an analysis of corporate investment decisions, Working paper.

Baum, C. F., Caglayan, M. and Talavera, O. (2008). Uncertainty determinants of firm investment, Economics Letters 98(3): 282-287.

Berk, J. B., Green, R. C. and Naik, V. (1999). Optimal investment, growth options, and security returns, Journal of Finance 54(5): 1553-1607.

Bloom, N. (2009). The impact of uncertainty shocks, Econometrica 77(3): 623-685.

Bloom, N., Bond, S. and Reenen, J. V. (2007). Uncertainty and investment dynamics, Review of Economic Studies 74(2): 391-415.

Bond, S. R. and Cummins, J. G. (2004). Uncertainty and investment: an empirical investigation using data on analysts' profits forecasts, Technical report.

Brainard, W. C., Shoven, J. B., Weiss, L., Cagan, P. and Hall, R. E. (1980). The financial valuation of the return to capital, Brookings Papers on Economic Activity 1980(2): 453511.

Bulan, L. T. (2005). Real options, irreversible investment and firm uncertainty: New evidence from u.s. firms, Review of Financial Economics 14(3-4): 255-279.

Caballero, R. J. (1991). On the sign of the investment-uncertainty relationship, American Economic Review 81(1): 279-88.

Campbell, J. Y., Lettau, M., Malkiel, B. G. and Xu, Y. (2001). Have individual stocks become more volatile? an empirical exploration of idiosyncratic risk, Journal of Finance 56(1): 1-43. 
Chen, H., Miao, J. and Wang, N. (2009). Entrepreneurial finance and non-diversifiable risk, NBER Working Papers 14848, National Bureau of Economic Research, Inc.

Core, J. and Guay, W. (2002). Estimating the value of employee stock option portfolios and their sensitivities to price and volatility, Journal of Accounting Research 40(3): 613-630.

Cummins, J. G., Hassett, K. A. and Oliner, S. D. (2006). Investment behavior, observable expectations, and internal funds, American Economic Review 96(3): 796-810.

Curcuru, S., Heaton, J., Lucas, D. and Moore, D. (2004). Heterogeneity and portfolio choice: Theory and evidence, Handbook of Financial Econometrics .

Eberly, J. C. (1997). International evidence on investment and fundamentals, European Economic Review 41(6): 1055-1078.

Erickson, T. and Whited, T. M. (2000). Measurement error and the relationship between investment and q, Journal of Political Economy 108(5): 1027-1057.

Fama, E. F. and French, K. R. (1997). Industry costs of equity, Journal of Financial Economics 43(2): 153 - 193.

Fama, E. F. and MacBeth, J. D. (1973). Risk, return, and equilibrium: Empirical tests, Journal of Political Economy 81(3): 607-36.

Froot, K. A., Scharfstein, D. S. and Stein, J. C. (1993). Risk management: Coordinating corporate investment and financing policies, Journal of Finance 48(5): 1629-58.

Gala, V. and Julio, B. (2009). Size effects in corporate investments, Working paper, London Business School.

Gatchev, V., Pulvino, T. and Tarhan, V. (2008). The interdependent and intertemporal nature of financial decisions: An application to cash flow sensitivities, Working paper.

Hart, O. D. (1983). The market mechanism as an incentive scheme, The Bell Journal of Economics 14(2): 366-382.

Hartman, R. (1972). The effects of price and cost uncertainty on investment, Journal of Economic Theory 5(2): 258-266.

Heaton, J. and Lucas, D. (2000a). Portfolio choice and asset prices: The importance of entrepreneurial risk, Journal of Finance 55(3): 1163-1198.

Heaton, J. and Lucas, D. (2000b). Portfolio choice in the presence of background risk, Economic Journal 110(460): 1-26.

Henderson, V. (2007). Valuing the option to invest in an incomplete market, Mathematics and Financial Economics 1(2): 103-128.

Henley, A., Carruth, A. and Dickerson, A. (2003). Industry-wide versus firm-specific uncertainty and investment: British company panel data evidence, Economics Letters 78(1): 87-92. 
Hennessy, C. A. (2004). Tobin's "q", debt overhang, and investment, Journal of Finance 59(4): 1717-1742.

Himmelberg, C. P., Hubbard, R. G. and Love, I. (2002). Investment, protection, ownership, and the cost of capital, Policy Research Working Paper 2834, World Bank.

Holmstrom, B. (1979). Moral hazard and observability, The Bell Journal of Economics 10(1): 74-91.

Hugonnier, J. and Morellec, E. (2007a). Corporate control and real investment in incomplete markets, Journal of Economic Dynamics and Control 31(5): 1781 - 1800.

Hugonnier, J. and Morellec, E. (2007b). Real options and risk aversion, Working paper.

Kleibergen, F. and Paap, R. (2006). Generalized reduced rank tests using the singular value decomposition, Journal of Econometrics 133(1): 97-126.

Knopf, J. D., Nam, J. and Jr., J. H. T. (2002). The volatility and price sensitivities of managerial stock option portfolios and corporate hedging, Journal of Finance 57(2): 801-813.

Kogan, L. and Papanikolaou, D. (2009). Growth opportunities and technology shocks, Working paper.

Leahy, J. V. and Whited, T. M. (1996). The effect of uncertainty on investment: Some stylized facts, Journal of Money, Credit and Banking 28(1): 64-83.

Miao, J. and Wang, N. (2007). Investment, consumption, and hedging under incomplete markets, Journal of Financial Economics 86(3): 608 - 642.

Moskowitz, T. J. and Vissing-Jørgensen, A. (2002). The returns to entrepreneurial investment: A private equity premium puzzle?, American Economic Review 92(4): 745-778.

Nagel, S. (2005). Short sales, institutional investors and the cross-section of stock returns, Journal of Financial Economics 78(2): 277-309.

Nakamura, T. (1999). Risk-aversion and the uncertainty-investment relationship: a note, Journal of Economic Behavior \&3 Organization 38(3): 357 - 363.

Oi, W. Y. (1961). The desirability of price instability under perfect competition, Econometrica 29(1): 58-64.

Panousi, V. (2008). Capital taxation with entrepreneurial risk, Working paper, Federal Reserve Board of Governors.

Raith, M. (2003). Competition, risk, and managerial incentives, American Economic Review 93(4): $1425-1436$.

Ridick, L. A. and Whited, T. (2008). The corporate propensity to save, Journal of Finance, forthcoming . 
Ross, S. A. (2004). Compensation, incentives, and the duality of risk aversion and riskiness, The Journal of Finance 59: 207-225(19).

Saltari, E. and Ticchi, D. (2007). Risk aversion, intertemporal substitution, and the aggregate investment-uncertainty relationship, Journal of Monetary Economics 54(3): 622-648.

Scharfstein, D. (1988). Product-market competition and managerial slack, The RAND Journal of Economics 19(1): 147-155.

Schmidt, K. M. (1997). Managerial incentives and product market competition, Review of Economic Studies 64(2): 191-213.

Shleifer, A. and Vishny, R. W. (1992). Liquidation values and debt capacity: A market equilibrium approach, Journal of Finance 47(4): 1343-66.

Stock, J. H. and Yogo, M. (2002). Testing for weak instruments in linear iv regression, NBER Technical Working Papers 0284, National Bureau of Economic Research, Inc.

Vissing-Jørgensen, A. (2002). Limited asset market participation and the elasticity of intertemporal substitution, Journal of Political Economy 110(4): 825-853.

Whited, T. M. and Wu, G. (2006). Financial Constraints Risk, Review of Financial Studies 19(2): 531-559. 


\section{Tables}

Table 1: Data Definitions

\begin{tabular}{|c|c|c|}
\hline variable & Definition & Source \\
\hline$I$ & Investment (CAPEX) & COMPUSTAT Item128 \\
\hline$K$ & apital (PPE) & COMPUSTAT Item8 \\
\hline$C F$ & Cashflow & COMPUSTAT Item14 + COMPUSTAT Item18 \\
\hline$E$ & Book Value of Equity & COMPUSTAT Item216 \\
\hline$A$ & Book Value of Assets & COMPUSTAT Item6 \\
\hline$Q$ & Tobin's Q & $\begin{array}{l}\text { (CRSP Market Cap of Equity + Book Assets - Book Com- } \\
\text { mon Equity (Item60) - Deferred Taxes (item74)) / Book } \\
\text { Assets }\end{array}$ \\
\hline$R$ & Stock Return & CRSP Stock Return \\
\hline$S$ & Net Sales & COMPUSTAT Item12 \\
\hline$L$ & Number of Employees & COMPUSTAT Item29 \\
\hline$T A N G$ & Asset Tangibility & COMPUSTAT Item8 / COMPUSTAT Item6 \\
\hline$M K C A P$ & Market Capitalization & December value of market equity from CRSP \\
\hline$C A S H$ & Cash Holdings & COMPUSTAT Item1 \\
\hline$D I V$ & Dividend Payout & COMPUSTAT Item19 + COMPUSTAT Item21 \\
\hline$D I V P O S$ & Dividend Payout Indicator & 1 if $\mathrm{DIV}>0$ \\
\hline$L E V$ & Financial Leverage & $\begin{array}{l}\text { COMPUSTAT (Item } 9+\text { Item34) } \\
/ \text { COMPUSTAT }(\text { Item } 9+\text { Item } 34+\text { Item216) }\end{array}$ \\
\hline$A C Q$ & Acqu & COMPUSTAT Item129 / COMPUSTAT (L. Item8) \\
\hline$A S A L E$ & PPE & COMPUSTAT Item107 / CO \\
\hline$R E P$ & of Com. and Pref. Stock & COMPUSTAT Item115 / CO \\
\hline$E Q I S S$ & Sale & COMPUSTAT Item108 / COMI \\
\hline$\triangle S T D$ & Char & $\Delta($ COMPUSTAT Item34) $/ \mathrm{COM}$ \\
\hline$\triangle L T D$ & in Long-Term Debt & $\Delta$ (COMPUSTAT Item9) / COMPUSTAT (L. Item8) \\
\hline$S G$ & Sale: & $\log ($ COMPUSTAT Item12)- $\log ($ COMPUSTAT L.Item12) \\
\hline$S I C 3$ & ssification & Standardized Industry Classification Codes \\
\hline$I S G$ & IC3-Industry Sales Growth & $\Delta \log (S I C 3$-Industry Sales Gro \\
\hline$R E$ & xpenditure & COMPUSTAT Item47 / COMPUSTAT Item8 \\
\hline$D E$ & Depreciation Rate & $\begin{array}{l}\text { COMPUSTAT Item103 / COMPUSTAT Item8; if COM- } \\
\text { PUSTAT Item103 is N/A, then COMPUSTAT (Item14 - } \\
\text { Item65) / COMPUSTAT Item8 }\end{array}$ \\
\hline$H H$ & Herfi & Sum of squared market (sales) shares for firms in industry \\
\hline$W W$ & Whited \& Wu Index & 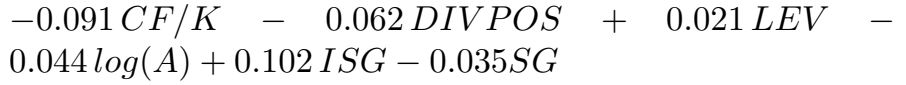 \\
\hline QIBES & $\mathrm{A}$ & See Text \\
\hline & c Volatility & See Text \\
\hline$\sigma^{i d i o}$ & atic Volatility & See Text \\
\hline$R_{M K T}$ & Portfolio & CRSP Value-Weighted Index \\
\hline$R_{I N D}$ & Industry Return & $\begin{array}{l}\text { VW index of returns of firms in the same industry. We } \\
\text { group stocks into } 12 \text { industries accroding to Fama and } \\
\text { French (1997). }\end{array}$ \\
\hline$R \& D$ & Investment in $\mathrm{R} \& \mathrm{D}$ & COMPUSTAT Item46 \\
\hline
\end{tabular}


Table 2: Benchmark

\begin{tabular}{|c|c|c|c|c|c|c|c|c|}
\hline \multirow{2}{*}{$\begin{array}{l}i_{t} \\
\log \left(\sigma_{i, t-1}\right)\end{array}$} & No Controls & Q, ROE & BENCH & All+IT & Syst & \multicolumn{2}{|c|}{$i_{t-1}$} & R\&D \\
\hline & $\begin{array}{l}-0.0458 \\
(-19.28)\end{array}$ & $\begin{array}{l}-0.0255 \\
(-10.55)\end{array}$ & $\begin{array}{l}-0.0376 \\
(-15.56)\end{array}$ & $\begin{array}{l}-0.0373 \\
(-15.45)\end{array}$ & $\begin{array}{l}-0.0445 \\
(-17.60)\end{array}$ & $\begin{array}{l}-0.0206 \\
(-11.99)\end{array}$ & $\begin{array}{c}-0.0240 \\
(-9.65)\end{array}$ & $\begin{array}{c}-0.0452 \\
(-4.04)\end{array}$ \\
\hline $\log \left(\sigma_{t-1}^{s y s t}\right)$ & & & & & $\begin{array}{c}0.0092 \\
(8.57)\end{array}$ & & & \\
\hline $\log \left(Q_{t-1}\right)$ & & $\begin{array}{l}0.1161 \\
(38.59)\end{array}$ & $\begin{array}{l}0.0926 \\
(28.65)\end{array}$ & $\begin{array}{l}0.0876 \\
(27.05)\end{array}$ & $\begin{array}{l}0.0905 \\
(27.94)\end{array}$ & $\begin{array}{l}0.0446 \\
(26.04)\end{array}$ & $\begin{array}{l}0.0593 \\
(13.01)\end{array}$ & $\begin{array}{l}0.0959 \\
(5.91)\end{array}$ \\
\hline$C F_{t-1} / K_{t-2}$ & & $\begin{array}{l}0.0368 \\
(23.41)\end{array}$ & $\begin{array}{l}0.0295 \\
(20.48)\end{array}$ & $\begin{array}{l}0.0288 \\
(19.95)\end{array}$ & $\begin{array}{l}0.0293 \\
(20.39)\end{array}$ & $\begin{array}{l}0.0207 \\
(20.10)\end{array}$ & $\begin{array}{l}0.0155 \\
(8.34)\end{array}$ & $\begin{array}{c}0.0074 \\
(0.61)\end{array}$ \\
\hline $\log \left(\hat{K}_{t-1}\right)$ & & & $\begin{array}{l}-0.0531 \\
(-31.67)\end{array}$ & $\begin{array}{l}-0.0554 \\
(-32.59)\end{array}$ & $\begin{array}{l}-0.0543 \\
(-32.25)\end{array}$ & $\begin{array}{l}-0.0085 \\
(-19.35)\end{array}$ & $\begin{array}{l}-0.2786 \\
(-50.15)\end{array}$ & $\begin{array}{l}-0.2226 \\
(-14.41)\end{array}$ \\
\hline$R_{t-1}$ & & & $\begin{array}{l}0.0293 \\
(19.22)\end{array}$ & $\begin{array}{l}0.0287 \\
(18.59)\end{array}$ & $\begin{array}{l}0.0295 \\
(19.35)\end{array}$ & $\begin{array}{l}0.0519 \\
(38.56)\end{array}$ & $\begin{array}{c}0.0110 \\
(6.77)\end{array}$ & $\begin{array}{c}0.0059 \\
(0.81)\end{array}$ \\
\hline $\log \left(E_{t-1} / A_{t-1}\right)$ & & & $\begin{array}{l}0.0432 \\
(18.58)\end{array}$ & $\begin{array}{l}0.0428 \\
(18.66)\end{array}$ & $\begin{array}{l}0.0425 \\
(18.29)\end{array}$ & $\begin{array}{l}0.0192 \\
(14.85)\end{array}$ & $\begin{array}{c}0.0447 \\
(12.83)\end{array}$ & $\begin{array}{c}0.0648 \\
(5.32)\end{array}$ \\
\hline$I_{t-1} / K_{t-2}$ & & & & & & $\begin{array}{l}0.3697 \\
(83.52)\end{array}$ & $\begin{array}{l}0.1280 \\
(16.70)\end{array}$ & \\
\hline $\begin{array}{l}\text { Observations } \\
R^{2}\end{array}$ & $\begin{array}{l}84097 \\
0.305\end{array}$ & $\begin{array}{l}84097 \\
0.401\end{array}$ & $\begin{array}{l}84097 \\
0.441\end{array}$ & $\begin{array}{l}84097 \\
0.451\end{array}$ & $\begin{array}{l}84097 \\
0.442\end{array}$ & $\begin{array}{l}84097 \\
0.349\end{array}$ & 66983 & $\begin{array}{l}46415 \\
0.777\end{array}$ \\
\hline $\begin{array}{l}m_{2} \\
p(J)\end{array}$ & & & & & & & $\begin{array}{l}0.12 \\
0.00\end{array}$ & \\
\hline Fixed Effects & $\bar{F}$ & $\mathrm{~F}, \mathrm{~T}$ & $\mathrm{~F}, \mathrm{~T}$ & $\mathrm{~F}, I \times T$ & $\mathrm{~F}, \mathrm{~T}$ & $\mathrm{I}, \mathrm{T}$ & $\mathrm{F}, \mathrm{T}$ & $\mathrm{F}, \mathrm{T}$ \\
\hline Estimation Method & OLS & OLS & OLS & OLS & OLS & OLS & GMM & OLS \\
\hline
\end{tabular}

Table 2 reports estimation results of Equation (11), where the dependent variable is the investment rate $\left(I_{t} / K_{t-1}\right)$. Our baseline measure of risk, $\sigma_{t-1}$, is constructed from a regression of weekly firm-level returns on the CRSP VW index and the corresponding industry portfolio. Additional regressors include lagged values of systematic volatility $\left(\sigma_{t-1}^{\text {syst }} \equiv \sqrt{\left(\sigma_{t-1}^{\text {total }}\right)^{2}-\sigma_{i, t-1}^{2}}\right)$, Tobin's Q $\left(Q_{t-1}\right)$, operating cashflows $\left(C F_{t-1} / K_{t-2}\right)$, the firm's capital stock relative to the aggregate $\left(\hat{K}_{t-1}=K_{i, t} / \frac{1}{N_{f}} \sum_{i}^{N_{f}} K_{i, t}\right)$, the firm's stock return $\left(R_{t-1}\right)$, and leverage $\left(E_{t-1} / A_{t-1}\right)$. R\&D Investment refers to Research and Development Expenses (Item46) over Capital (Item8). The sample period is $1970-2005$. We include firm- and time-fixed effects. The standard errors are clustered at the firm-level, and $t$-statistics are reported in parenthesis. The sixth column presents results using the Arrellano-Bond estimator, where the lagged investment rate is included in the specification. 
Table 3: Sources vs. Uses

\begin{tabular}{ll|ccccccccc}
\hline \hline $\mathrm{CN}$ & $C F_{1}$ & CAPEX & ACQ & ASALE & DIV & REP & EQUISS & $\Delta$ Cash & $\Delta$ STD & $\Delta$ LTD \\
\hline \multirow{2}{*}{$\mathrm{N}$} & \multirow{2}{*}{$\mathrm{N}$} & -0.0376 & -0.0845 & 0.0035 & -0.0197 & -0.0266 & 0.0072 & 0.0848 & -0.0291 & -0.0103 \\
& & $(-15.56)$ & $(-2.00)$ & $(1.36)$ & $(-4.28)$ & $(-4.40)$ & $(0.47)$ & $(4.04)$ & $(-2.29)$ & $(-0.55)$ \\
\hline \multirow{2}{*}{$\mathrm{Y}$} & \multirow{2}{*}{$\mathrm{N}$} & -0.0383 & -0.0685 & 0.0069 & -0.0147 & -0.0636 & 0.0496 & 0.1800 & -0.0259 & -0.0357 \\
& & $(-7.28)$ & $(-1.94)$ & $(1.69)$ & $(-3.57)$ & $(-4.53)$ & $(1.05)$ & $(3.24)$ & $(-1.32)$ & $(-0.81)$ \\
\hline \multirow{2}{*}{$\mathrm{N}$} & \multirow{2}{*}{$\mathrm{Y}$} & -0.0370 & -0.0822 & 0.0037 & -0.0187 & -0.0249 & 0.0046 & 0.1110 & -0.0305 & -0.0073 \\
& & $(-14.82)$ & $(-1.95)$ & $(1.47)$ & $(-3.98)$ & $(-4.24)$ & $(0.30)$ & $(5.28)$ & $(-2.43)$ & $(-0.40)$ \\
\hline \multirow{2}{*}{$\mathrm{Y}$} & \multirow{2}{*}{$\mathrm{Y}$} & -0.0374 & -0.0654 & 0.0071 & -0.0147 & -0.0617 & 0.0524 & 0.1897 & -0.0269 & -0.0221 \\
& & $(-7.20)$ & $(-1.85)$ & $(1.78)$ & $(-3.61)$ & $(-4.41)$ & $(1.11)$ & $(3.43)$ & $(-1.37)$ & $(-0.51)$ \\
\hline \hline
\end{tabular}

Table 3 reports the coefficients of the lagged baseline measure of idiosyncratic volatility, $\sigma_{t-1}$, on each one of the following current-period dependent variables: capital expenditure, acquisitions, dividends, purchases of stock, changes in cash, sales of assets, changes in short-term debt, and changes in long-term debt. The sample period is $1970-2005$. If $C F_{1}=N$, then the specification is as in the benchmark Equation (11), i.e. the regressors include lagged values of our baseline measure of idiosyncratic volatility $\left(\sigma_{t-1}\right)$, Tobin's Q $\left(Q_{t-1}\right)$, operating cashflows $\left(C F_{t-1} / K_{t-2}\right)$, the firm's capital stock relative to the aggregate $\left(\hat{K}_{t-1}=\right.$ $\left.K_{i, t} / \frac{1}{N_{f}} \sum_{i}^{N_{f}} K_{i, t}\right)$, the firm's stock return $\left(R_{t-1}\right)$, leverage $\left(E_{t-1} / A_{t-1}\right)$, firm- and time-fixed effects. If $C F_{1}=Y$, then the specification is as in the benchmark Equation 11 with current cashflows $\left(C F_{t} / K_{t-1}\right)$ added as a regressor. If $C N=N$, then each one of the nine equations is estimated separately. If $C N=Y$, then the cross-sectional constraint $\Delta$ (Sources $)=\Delta($ Uses $)$ is imposed, and the estimation procedure uses SUR. In the single-equation regressions the standard errors are clustered at the firm-level. $t$-statistics are always reported in parenthesis. 
Table 4: Measurement error in $Q$

\begin{tabular}{|c|c|c|c|c|c|c|}
\hline \multirow[b]{2}{*}{$\log \left(\sigma_{i, t-1}\right)$} & \multicolumn{2}{|c|}{$\overline{Q^{i b e s}}$} & \multicolumn{2}{|c|}{$\beta^{i m c}$} & \multirow{2}{*}{$\begin{array}{c}\text { OLS } \\
-0.0445 \\
(-17.82)\end{array}$} & \multirow{2}{*}{$\begin{array}{c}E W_{3} \\
-0.0463 \\
(-5.28)\end{array}$} \\
\hline & $\begin{array}{c}-0.0212 \\
(-5.01)\end{array}$ & $\begin{array}{c}-0.0182 \\
(-4.38)\end{array}$ & $\begin{array}{l}-0.0467 \\
(-16.10)\end{array}$ & $\begin{array}{l}-0.0359 \\
(-12.77)\end{array}$ & & \\
\hline $\log \left(Q_{t-1}^{\text {ibes }}\right)$ & $\begin{array}{l}0.0451 \\
(21.23)\end{array}$ & $\begin{array}{l}0.0316 \\
(14.10)\end{array}$ & & & & \\
\hline$\beta_{t-1}^{i m c}$ & & & $\begin{array}{c}0.0068 \\
(7.07)\end{array}$ & $\begin{array}{l}0.0048 \\
(5.08)\end{array}$ & & \\
\hline $\log \left(Q_{t-1}\right)$ & & $\begin{array}{l}0.0704 \\
(11.47)\end{array}$ & & $\begin{array}{l}0.0939 \\
(24.98)\end{array}$ & & \\
\hline$Q_{t-1}$ & & & & & $\begin{array}{l}0.0195 \\
(10.70)\end{array}$ & $\begin{array}{l}0.0307 \\
(1.21)\end{array}$ \\
\hline$C F_{t-1} / K_{t-2}$ & $\begin{array}{c}0.0354 \\
(9.93)\end{array}$ & $\begin{array}{c}0.0326 \\
(9.32)\end{array}$ & $\begin{array}{l}0.0354 \\
(14.35)\end{array}$ & $\begin{array}{l}0.0308 \\
(13.74)\end{array}$ & $\begin{array}{l}0.0328 \\
(21.76)\end{array}$ & $\begin{array}{l}0.0572 \\
(4.95)\end{array}$ \\
\hline $\log \left(\hat{K}_{t-1}\right)$ & $\begin{array}{l}-0.0647 \\
(-19.34)\end{array}$ & $\begin{array}{l}-0.0658 \\
(-19.66)\end{array}$ & $\begin{array}{l}-0.0536 \\
(-25.75)\end{array}$ & $\begin{array}{l}-0.0511 \\
(-25.04)\end{array}$ & $\begin{array}{l}-0.0543 \\
(-32.19)\end{array}$ & $\begin{array}{c}-0.0564 \\
(-8.98)\end{array}$ \\
\hline$R_{t-1}$ & $\begin{array}{l}0.0398 \\
(15.04)\end{array}$ & $\begin{array}{c}0.0236 \\
(8.18)\end{array}$ & $\begin{array}{l}0.0545 \\
(31.13)\end{array}$ & $\begin{array}{l}0.0316 \\
(17.20)\end{array}$ & $\begin{array}{l}0.0421 \\
(26.69)\end{array}$ & $\begin{array}{l}0.0471 \\
(3.13)\end{array}$ \\
\hline $\log \left(E_{t-1} / A_{t-1}\right)$ & $\begin{array}{c}0.0255 \\
(5.31)\end{array}$ & $\begin{array}{c}0.0287 \\
(5.97)\end{array}$ & $\begin{array}{c}0.0366 \\
(12.82)\end{array}$ & $\begin{array}{c}0.0428 \\
(15.18)\end{array}$ & $\begin{array}{c}0.0376 \\
(16.21)\end{array}$ & $\begin{array}{c}0.0358 \\
(11.70)\end{array}$ \\
\hline $\begin{array}{l}\text { Observations } \\
R^{2} \\
\tau^{2}\end{array}$ & $\begin{array}{c}25433 \\
0.608\end{array}$ & $\begin{array}{c}25433 \\
0.614\end{array}$ & $\begin{array}{c}60622 \\
0.420\end{array}$ & $\begin{array}{c}60622 \\
0.440\end{array}$ & $\begin{array}{c}84097 \\
0.429\end{array}$ & 84097 \\
\hline $\begin{array}{l}\text { Fixed Effects } \\
\text { Estimation Method }\end{array}$ & $\begin{array}{l}\mathrm{F}, \mathrm{T} \\
\text { OLS }\end{array}$ & $\begin{array}{l}\mathrm{F}, \mathrm{T} \\
\text { OLS }\end{array}$ & $\begin{array}{l}\mathrm{F}, \mathrm{T} \\
\text { OLS }\end{array}$ & $\begin{array}{l}\mathrm{F}, \mathrm{T} \\
\text { OLS }\end{array}$ & $\begin{array}{l}\mathrm{F}, \mathrm{T} \\
\text { OLS }\end{array}$ & $\begin{array}{l}0.323 \\
\mathrm{~F}, \mathrm{~T} \\
\mathrm{GMM}\end{array}$ \\
\hline
\end{tabular}

Table 4 reports estimation results of a modified version Equation [11), where the dependent variable is the investment rate $\left(I_{t} / K_{t-1}\right)$. Our baseline measure of risk, $\sigma_{t-1}$, is constructed from a regression of weekly firm-level returns on the CRSP VW index and the corresponding industry portfolio. Additional regressors include Tobin's Q $\left(Q_{t-1}\right)$, operating cashflows $\left(C F_{t-1} / K_{t-2}\right)$, firm capital stock relative to the aggregate $\left(K_{t-1}=k_{i, t} / \frac{1}{N_{f}} \sum_{i}^{N_{f}} k_{i, t}\right)$, the firm's stock return $\left(R_{t-1}\right)$, leverage $\left(E_{t-1} / A_{t-1}\right)$, The $Q$ measure constructed from analyst forecasts $Q^{i b e s}$ and $\beta^{i m c}$. The construction of $Q^{i b e s}$ is detailed in the main text and follows Cummins et al. (2006). $\beta^{i m c}$ is the firm's univariate beta with a portfolio long the capital-goods producing sector and short the consumption-producing sector. Its construction is detailed in Kogan and Papanikolaou (2009). $t$-statistics based on standard errors clustered by firm are reported in parenthesis. 
Table 5: Volatility Instrumented by Concentration of Sales

\begin{tabular}{|c|c|c|c|c|}
\hline \multicolumn{2}{|c|}{ First Stage } & \multicolumn{3}{|c|}{ Second Stage } \\
\hline$H_{t-1}$ & $\begin{array}{c}(1) \\
0.1170 \\
(5.24)\end{array}$ & $\log \left(\sigma_{i, t-1}\right)$ & $\begin{array}{c}(1) \\
-0.153 \\
(-2.23)\end{array}$ & $\begin{array}{c}(2) \\
-0.0253 \\
(-8.15)\end{array}$ \\
\hline $\log \left(Q_{t-1}\right)$ & $\begin{array}{c}-0.0705 \\
(-7.95)\end{array}$ & $\log \left(Q_{t-1}\right)$ & $\begin{array}{c}0.0414 \\
(7.31)\end{array}$ & $\begin{array}{c}0.0500 \\
(17.26)\end{array}$ \\
\hline$C F_{t-1} / K_{t-2}$ & $\begin{array}{l}-0.0411 \\
(-15.42)\end{array}$ & $C F_{t-1} / K_{t-2}$ & $\begin{array}{c}0.0082 \\
(2.57)\end{array}$ & $\begin{array}{c}0.0135 \\
(9.63)\end{array}$ \\
\hline $\log \left(\hat{K}_{t-1}\right)$ & $\begin{array}{l}-0.1390 \\
(-52.19)\end{array}$ & $\log \left(\hat{K}_{t-1}\right)$ & $\begin{array}{r}-0.0257 \\
(-2.67)\end{array}$ & $\begin{array}{c}-0.0078 \\
(-9.27)\end{array}$ \\
\hline$R_{t-1}$ & $\begin{array}{c}0.0386 \\
(8.00)\end{array}$ & $R_{t-1}$ & $\begin{array}{l}0.0530 \\
(15.08)\end{array}$ & $\begin{array}{c}0.0482 \\
(20.89)\end{array}$ \\
\hline $\log \left(E_{t-1} / A_{t-1}\right)$ & $\begin{array}{l}-0.1680 \\
(-20.00)\end{array}$ & $\log \left(E_{t-1} / A_{t-1}\right)$ & $\begin{array}{c}-0.0001 \\
(-0.00)\end{array}$ & $\begin{array}{c}0.0213 \\
(9.48)\end{array}$ \\
\hline$S_{t-1} / K_{t-2}$ & $\begin{array}{c}-0.0028 \\
(-6.41)\end{array}$ & $S_{t-1} / K_{t-2}$ & $\begin{array}{c}0.0010 \\
(3.78)\end{array}$ & $\begin{array}{c}0.0013 \\
(7.52)\end{array}$ \\
\hline$I_{t-1} / K_{t-2}$ & $\begin{array}{c}0.0070 \\
(0.43)\end{array}$ & $I_{t-1} / K_{t-2}$ & $\begin{array}{c}0.344 \\
(43.19)\end{array}$ & $\begin{array}{c}0.343 \\
(44.21) \\
\end{array}$ \\
\hline $\begin{array}{l}\text { Observations } \\
R^{2} \\
\mathrm{~F} \\
\mathrm{p}(\mathrm{F}) \\
\text { Fixed Effects }\end{array}$ & $\begin{array}{c}25256 \\
0.524 \\
204.68 \\
0.00 \\
\text { I,T }\end{array}$ & $\begin{array}{l}\text { Observations } \\
R^{2} \\
\text { KP rk Wald F statistic } \\
\text { SY Critical Values } \\
\text { Fixed Effects } \\
\text { Estimation Method }\end{array}$ & $\begin{array}{l}25256 \\
0.297 \\
27.50 \\
16.38 \\
\text { I,T } \\
\text { 2SLS }\end{array}$ & $\begin{array}{c}25256 \\
0.351\end{array}$ \\
\hline
\end{tabular}

Table 5 reports estimation results of a modified version of Equation (11) using instrumented variables. We report results separately for the first and second stage regressions. We instrument our baseline measure of idiosyncratic risk $\left(\sigma_{t-1}\right)$ with the concentration of a firm's customer base, $H_{i, t}$, constructed using customer data from the COMPUSTAT segment files (see text for details). The other regressors include lagged values of Tobin's Q $\left(Q_{t-1}\right)$, operating cashflows $\left(C F_{t-1} / K_{t-2}\right)$, the firm's capital stock relative to the aggregate $\left(\hat{K}_{t-1}=K_{i, t} / \frac{1}{N_{f}} \sum_{i}^{N_{f}} K_{i, t}\right)$, the firm's stock return $\left(R_{t-1}\right)$, leverage $\left(E_{t-1} / A_{t-1}\right)$, sales $\left(S_{t-1} / K_{t-2}\right)$, and the investment rate $\left(I_{t-1} / K_{t-2}\right)$. The sample period is $1977-2005$. We include industry-fixed effects. The first column includes time-fixed effects, the second column does not. The standard errors are clustered at the firm-level, and $t$-statistics are reported in parenthesis. We report the values of the Kleibergen-Paap (2006) $F$-statistic that tests for the null of weak instruments in the presence of non-iid errors. The critical values are from Stock and Yogo (2002), where the desired maximal bias of the IV estimator relative to OLS is 0.05. 


\begin{tabular}{lcccccc} 
Table 6: Summary Statistics: 5 & Portfolios Sorted & on Insider & Ownership \\
\cline { 1 - 6 } Portfolio & & Lo & 2 & 3 & 4 & Hi \\
\cline { 1 - 4 } Insider Ownership & & $0.1 \%$ & $0.3 \%$ & $0.9 \%$ & $3.2 \%$ & $16.2 \%$ \\
Tobin's $Q$ & & 1.298 & 1.332 & 1.324 & 1.313 & 1.285 \\
$\sigma$ & & $34.1 \%$ & $35.2 \%$ & $39.4 \%$ & $43.2 \%$ & $47.6 \%$ \\
Cashflows to Capital & & $26.7 \%$ & $30.7 \%$ & $32.1 \%$ & $31.5 \%$ & $30.7 \%$ \\
Investment to Capital & & $18.4 \%$ & $19.6 \%$ & $21.1 \%$ & $22.0 \%$ & $22.4 \%$ \\
Physical Capital to Book Assets & & $30.3 \%$ & $27.5 \%$ & $26.0 \%$ & $24.8 \%$ & $24.3 \%$ \\
Debt to Assets & & $32.9 \%$ & $31.4 \%$ & $28.5 \%$ & $26.3 \%$ & $25.2 \%$ \\
Cash to Assets & & $19.0 \%$ & $21.0 \%$ & $24.2 \%$ & $28.5 \%$ & $30.6 \%$ \\
Dividends to Cashflows & & $4.8 \%$ & $3.3 \%$ & $2.5 \%$ & $0.3 \%$ & $0.0 \%$ \\
$V / \bar{V}$ & $37.9 \%$ & $29.0 \%$ & $17.5 \%$ & $10.5 \%$ & $5.2 \%$ \\
\hline \hline
\end{tabular}

Table 6 shows time-series averages of characteristics of the 5 portfolios sorted levels of insider ownership. Every year, we sort firms into quintiles based on the fraction of shares outstanding owned by company officers. The data on ownership is from Thomson Financial and contains all Table 1 transaction and holdings information filed on Forms 3,4 and 5. We restrict attention to insiders with role codes O, OD, OE, OB, OP, OS, OT, OX, CEO, CFO, CI, CO, CT, H, GM, M, MD, P, EVP, VP, and SVP. We normalize the shares owned by insiders by CRSP shares outstanding (shrout). We use medians as measures of portfolio characteristics except the last row which shows each portfolio's market capitalization as a fraction of the total. Tobin's Q is computed as December market capitalization plus book value of debt plus book value of preferred stock minus book value of common equity, inventories and deferred taxes, divided by book assets. We compute $\sigma$ as the standard deviation of the residual of a regression of firm stock returns on the market portfolio and the corresponding industry portfolio. We use weekly data and estimate the regression for every firm and every year. The sample period is $1986-2005$. 


\section{Table 7: Effect of Insider Ownership}

\begin{tabular}{lccccc}
\hline \hline Insider Ownership & $(0,20]$ & {$[20,40]$} & {$[40,60]$} & {$[60,80]$} & {$[80,100]$} \\
\cline { 2 - 6 } $\log \left(\sigma_{i, t-1}\right)$ & -0.0293 & -0.0323 & -0.0451 & -0.0615 & -0.0533 \\
$R^{2}$ & $(-3.25)$ & $(-3.34)$ & $(-4.36)$ & $(-5.10)$ & $(-4.69)$ \\
\cline { 2 - 6 } Chow $\chi^{2}$ & 0.644 & 0.672 & 0.664 & 0.625 & 0.601 \\
$\mathrm{p}-$ value & & & & & 4.41 \\
\hline $\log \left(\sigma_{i, t-1}\right)$ & -0.0296 & -0.0206 & -0.0165 & -0.0398 & -0.0506 \\
& $(-3.12)$ & $(-2.10)$ & $(-1.59)$ & $(-3.35)$ & $(-4.53)$ \\
$\log \left(Q_{t-1}\right)$ & 0.0810 & 0.0952 & 0.0950 & 0.1116 & 0.0921 \\
& $(6.42)$ & $(6.72)$ & $(6.91)$ & $(8.19)$ & $(7.02)$ \\
$c_{t-1} / K_{t-2}$ & 0.0182 & 0.0157 & 0.0326 & 0.0265 & 0.0227 \\
& $(2.37)$ & $(2.13)$ & $(5.59)$ & $(5.16)$ & $(5.49)$ \\
$\log \left(\hat{K}_{t-1}\right)$ & & & & & \\
& -0.0833 & -0.0904 & -0.0892 & -0.1022 & -0.0978 \\
$R_{t-1}$ & $(-9.25)$ & $(-9.48)$ & $(-9.81)$ & $(-9.98)$ & $(-11.11)$ \\
& & & & & \\
$\log \left(E_{t-1} / A_{t-1}\right)$ & 0.0099 & 0.0192 & 0.0203 & 0.0135 & 0.0119 \\
$R^{2}$ & $(1.41)$ & $(2.78)$ & $(3.10)$ & $(2.01)$ & $(1.86)$ \\
Chow $\chi^{2}$ & & & & & \\
$\mathrm{p}-$ value & $(3.39)$ & $(4.90)$ & $(3.47)$ & $(3.96)$ & $(3.62)$ \\
\hline Total Observations & 0.713 & 0.744 & 0.743 & 0.714 & 0.683 \\
\hline \hline
\end{tabular}

Table 7 reports estimation results of Equation (11) separately for firms with different levels of insider ownership. Every year, we sort firms into quintiles based on the fraction of shares outstanding owned by company officers. We split the observations with ownership values that are not missing or zero into five quintiles. We report estimation results for the missing or zero group separately. The data on ownership is from Thomson Financial and contains all Table 1 transaction and holdings information filed on Forms 3,4 and 5. We restrict attention to insiders with role codes $\mathrm{O}, \mathrm{OD}, \mathrm{OE}, \mathrm{OB}, \mathrm{OP}, \mathrm{OS}, \mathrm{OT}$, OX, CEO, CFO, CI, CO, CT, H, GM, M, MD, P, EVP, VP, and SVP. The sample period is $1986-2005$. The dependent variable is the investment rate $\left(I_{t} / K_{t-1}\right)$. The regressors include lagged values of our baseline measure of idiosyncratic volatility $\left(\sigma_{t-1}\right)$, Tobin's $\mathrm{Q}\left(Q_{t-1}\right)$, operating cashflows $\left(C F_{t-1} / K_{t-2}\right)$, the firm's capital stock relative to the aggregate $\left(\hat{K}_{t-1}=K_{i, t} / \frac{1}{N_{f}} \sum_{i}^{N_{f}} K_{i, t}\right)$, the firm's stock return $\left(R_{t-1}\right)$, and leverage $\left(E_{t-1} / A_{t-1}\right)$. The top panel includes firm effects, the bottom panel includes firm- and time-fixed effects. We allow the unobserved firm and time fixed effect to vary across quantiles. The standard errors are clustered at the firm-level, and $t$-statistics are reported in parenthesis. We report the Chow $\chi^{2}$ test and the associated $p$-value for the null that the coefficient on idiosyncratic volatility, $\sigma_{t-1}$, is the same for quintiles 1 and 5 . 
Table 8: Effect of Insider's Option Exposure to Volatility

\begin{tabular}{lccccc}
\hline \hline Black-Scholes Vega & {$[0,20]$} & {$[20,40]$} & {$[40,60]$} & {$[60,80]$} & {$[80,100]$} \\
\hline $\log \left(\sigma_{i, t-1}\right)$ & -0.0797 & -0.0533 & -0.0264 & -0.0122 & -0.0112 \\
& $(-5.19)$ & $(-3.10)$ & $(-1.99)$ & $(-0.92)$ & $(-1.06)$ \\
\cline { 2 - 6 }$R^{2}$ & 0.624 & 0.621 & 0.723 & 0.694 & 0.640 \\
Chow $\chi^{2}$ & & & & & 19.34 \\
p-value & & & & & 0.000 \\
\hline $\log \left(\sigma_{i, t-1}\right)$ & -0.0454 & -0.0300 & -0.0139 & -0.0088 & -0.0171 \\
& $(-2.77)$ & $(-1.65)$ & $(-0.85)$ & $(-0.55)$ & $(-1.34)$ \\
$\log \left(Q_{t-1}\right)$ & 0.0967 & 0.1185 & 0.1003 & 0.1007 & 0.0699 \\
& $(4.71)$ & $(4.79)$ & $(4.42)$ & $(3.89)$ & $(3.88)$ \\
$c_{t-1} / K_{t-2}$ & & & & & \\
& 0.0385 & 0.0299 & 0.0156 & 0.0420 & 0.0395 \\
$\log \left(\hat{K}_{t-1}\right)$ & $(4.13)$ & $(2.96)$ & $(1.17)$ & $(3.67)$ & $(3.38)$ \\
& & & & & \\
$R_{t-1}$ & -0.0818 & -0.1201 & -0.1043 & -0.0976 & -0.0904 \\
& $(-5.79)$ & $(-7.89)$ & $(-6.91)$ & $(-6.83)$ & $(-7.75)$ \\
$\log \left(E_{t-1} / A_{t-1}\right)$ & 0.0221 & 0.0067 & 0.0139 & 0.0058 & 0.0057 \\
$R^{2}$ & $(2.32)$ & $(0.63)$ & $(1.19)$ & $(0.38)$ & $(0.70)$ \\
Chow $\chi^{2}$ & 0.0133 & 0.0330 & 0.0167 & 0.0263 & 0.0189 \\
\hline Total Observations & $(0.82)$ & $(1.27)$ & $(1.38)$ & $(1.35)$ & $(2.03)$ \\
\hline \hline & 0.728 & 0.719 & 0.792 & 0.770 & 0.740 \\
& & & & & 2.83 \\
& & & & & 0.095 \\
\hline
\end{tabular}

Table 8 reports estimation results of Equation (11) separately for firms where CEOs have different exposure to volatility. We measure Executives's exposure to volatility by computing the Black-Scholes derivative of the value of their option portfolio with respect to the volatility of the underlying $(\partial V / \partial \sigma)$, and aggregating within firm. The option data is from Execucomp. We use the methodology of Core and Guay (2002) to infer the strike prices and time to maturity for previously granted options. The sample period is $1992-2005$. The dependent variable is the investment rate $\left(I_{t} / K_{t-1}\right)$. The regressors include lagged values of our baseline measure of idiosyncratic volatility $\left(\sigma_{t-1}\right)$, Tobin's $\mathrm{Q}\left(Q_{t-1}\right)$, operating cashflows $\left(C F_{t-1} / K_{t-2}\right)$, the firm's capital stock relative to the aggregate $\left(\hat{K}_{t-1}=K_{i, t} / \frac{1}{N_{f}} \sum_{i}^{N_{f}} K_{i, t}\right)$, the firm's stock return $\left(R_{t-1}\right)$, and leverage $\left(E_{t-1} / A_{t-1}\right)$. The top panel includes firm-fixed effects and the bottom panel includes firm- and time-fixed effects. We allow the unobserved firm and time fixed effect to vary across quantiles. The standard errors are clustered at the firm-level and $t$-statistics are reported in parenthesis. We report the Chow $\chi^{2}$ test and the associated $p$-value for the null that the coefficient on idiosyncratic volatility, $\sigma_{t-1}$, is the same for quintiles 1 and 5 . 

Table 9: Effect of Insider's Option Exposure to Volatility, controlling for Own-
ership

\begin{tabular}{|c|c|c|c|c|c|c|c|c|}
\hline Cont. & \multicolumn{4}{|c|}{ Ownership excl. options } & \multicolumn{4}{|c|}{ Ownership incl. options } \\
\hline \multirow{3}{*}{$\mathrm{N}$} & & Vega $=L$ & Vega $=H$ & $p$ & & Vega $=L$ & Vega $=H$ & $p$ \\
\hline & $\operatorname{Insd}=\mathrm{L}$ & $\begin{array}{c}-0.0658 \\
(-2.12)\end{array}$ & $\begin{array}{c}0.0025 \\
(0.18)\end{array}$ & 0.007 & $\operatorname{Insd}=\mathrm{L}$ & $\begin{array}{c}-0.0711 \\
(-2.28)\end{array}$ & $\begin{array}{l}0.0027 \\
(0.20)\end{array}$ & 0.003 \\
\hline & $\operatorname{Insd}=\mathrm{H}$ & $\begin{array}{c}-0.0900 \\
(-2.98)\end{array}$ & $\begin{array}{c}-0.0057 \\
(-0.22)\end{array}$ & 0.005 & $\operatorname{Insd}=\mathrm{H}$ & $\begin{array}{c}-0.0899 \\
(-2.97)\end{array}$ & $\begin{array}{c}-0.0085 \\
(-0.33)\end{array}$ & 0.006 \\
\hline \multirow[t]{2}{*}{$\mathrm{Y}$} & $\operatorname{Insd}=\mathrm{L}$ & $\begin{array}{c}\text { Vega }=L \\
-0.0529 \\
(-1.96)\end{array}$ & $\begin{array}{c}\text { Vega }=H \\
-0.0047 \\
(-0.29)\end{array}$ & $\begin{array}{c}p \\
0.011\end{array}$ & $\operatorname{Insd}=\mathrm{L}$ & $\begin{array}{c}\text { Vega }=\mathrm{L} \\
-0.0532 \\
(-1.98)\end{array}$ & $\begin{array}{c}\text { Vega }=H \\
-0.0042 \\
(-0.26)\end{array}$ & $\begin{array}{c}p \\
0.037\end{array}$ \\
\hline & $\operatorname{Insd}=\mathrm{H}$ & $\begin{array}{c}-0.0697 \\
(-2.63)\end{array}$ & $\begin{array}{c}0.0006 \\
(0.02)\end{array}$ & 0.041 & $\operatorname{Insd}=\mathrm{H}$ & $\begin{array}{c}-0.0678 \\
(-2.54)\end{array}$ & $\begin{array}{c}-0.0008 \\
(-0.03)\end{array}$ & 0.015 \\
\hline Obs & & & & 12,171 & & & & 12,116 \\
\hline
\end{tabular}

Table 9 reports estimation results of Equation (11) separately for firms with different levels of insider ownership and convexity of executive compensation. We use three measures of ownership. The first (top panel) uses data on ownership is from Thomson Financial and contains all Table 1 transaction and holdings information filed on Forms 3,4 and 5. We restrict attention to insiders with role codes O, OD, OE, OB, OP, OS, OT, OX, CEO, CFO, CI, CO, CT, H, GM, M, MD, P, EVP, VP, and SVP. The second (middle panel) ) uses data on ownership is from the COMPUSTAT executive compensation database, specifically the variables SHARES_EXCL_OPTS when available. The third (bottom panel) combines the two, giving preference to the first measure when possible. The left column reports results for the unadjusted measures, the right column adjusts these measures to account for the executive's option exposure (see main text for details). We measure compensation convexity by the Black-Scholes derivative of the value of their option portfolio with respect to the volatility of the underlying $(\partial V / \partial \sigma)$, and aggregating within firm. The option data is from Execucomp. We use the methodology of Core and Guay (2002) to infer the strike prices and time to maturity for previously granted options. Every year, we first sort firms into three equal sized groups based on ownership by insiders (High, Medium, Low), and then sort into three equal sized groups based sensitivity of compensation to volatility (High, Medium, Low). We report results for the four corners. The sample period is $1993-2005$. The dependent variable is the investment rate $\left(I_{t} / K_{t-1}\right)$. The regressors include lagged values of our baseline measure of idiosyncratic volatility $\left(\sigma_{t-1}\right)$, Tobin's $\mathrm{Q}\left(Q_{t-1}\right)$, operating cashflows $\left(C F_{t-1} / K_{t-2}\right)$, the firm's capital stock relative to the aggregate $\left(\hat{K}_{t-1}=K_{i, t} / \frac{1}{N_{f}} \sum_{i}^{N_{f}} K_{i, t}\right)$, the firm's stock return $\left(R_{t-1}\right)$, and leverage $\left(E_{t-1} / A_{t-1}\right)$. We include firm- and time-fixed effects. We allow the unobserved firm and time fixed effect to vary across quantiles. The standard errors are clustered at the firm-level, and $t$-statistics are reported in parenthesis. We report the Chow $\chi^{2}$ test and the associated $p$-value for the null that the idiosyncratic volatility, $\sigma_{t-1}$, coefficients on each row are the same. We report the Chow $\chi^{2}$ test and the associated $p$-value for the null that the idiosyncratic volatility coefficients, $\sigma_{t-1}$, on each row are the same. 


\section{Table 10: Effect of Financial Constraints}

\begin{tabular}{|c|c|c|c|c|c|c|c|}
\hline \multirow{4}{*}{$\log \left(\sigma_{i, t-1}\right)$} & \multicolumn{5}{|c|}{ Whited-Wu Index } & \multicolumn{2}{|c|}{ Have Rated Debt } \\
\hline & {$[0,20]$} & {$[20,40]$} & {$[40,60]$} & {$[60,80]$} & {$[80,100]$} & $\mathrm{N}$ & Y \\
\hline & -0.0317 & -0.0489 & -0.0519 & -0.0520 & -0.0458 & -0.0492 & -0.0392 \\
\hline & $(-6.85)$ & $(-9.06)$ & $(-8.78)$ & $(-8.17)$ & $(-7.28)$ & $(-17.97)$ & $(-8.49)$ \\
\hline$R^{2}$ & 0.440 & 0.435 & 0.462 & 0.441 & 0.366 & 0.307 & 0.412 \\
\hline Chow $\chi^{2}$ & & & & & 3.92 & & 3.86 \\
\hline p-value & & & & & 0.047 & & 0.049 \\
\hline $\log \left(\sigma_{i, t-1}\right)$ & $\begin{array}{c}-0.0179 \\
(-4.01)\end{array}$ & $\begin{array}{c}-0.0290 \\
(-5.57)\end{array}$ & $\begin{array}{c}-0.0255 \\
(-4.61)\end{array}$ & $\begin{array}{c}-0.0369 \\
(-5.91)\end{array}$ & $\begin{array}{c}-0.0454 \\
(-7.39)\end{array}$ & $\begin{array}{l}-0.0411 \\
(-14.73)\end{array}$ & $\begin{array}{c}-0.0251 \\
(-5.70)\end{array}$ \\
\hline $\log \left(Q_{t-1}\right)$ & $\begin{array}{c}0.0678 \\
(7.90)\end{array}$ & $\begin{array}{l}0.1035 \\
(13.22)\end{array}$ & $\begin{array}{c}0.1157 \\
(15.42)\end{array}$ & $\begin{array}{l}0.1087 \\
(12.79)\end{array}$ & $\begin{array}{c}0.0595 \\
(8.72)\end{array}$ & $\begin{array}{l}0.0941 \\
(26.67)\end{array}$ & $\begin{array}{l}0.1012 \\
(13.58)\end{array}$ \\
\hline$c_{t-1} / K_{t-2}$ & $\begin{array}{c}0.0797 \\
(6.59)\end{array}$ & $\begin{array}{c}0.0573 \\
(7.45)\end{array}$ & $\begin{array}{l}0.0465 \\
(7.93)\end{array}$ & $\begin{array}{c}0.0280 \\
(7.53)\end{array}$ & $\begin{array}{c}0.0178 \\
(8.74)\end{array}$ & $\begin{array}{l}0.0281 \\
(18.96)\end{array}$ & $\begin{array}{c}0.0425 \\
(6.61)\end{array}$ \\
\hline $\log \left(\hat{K}_{t-1}\right)$ & $\begin{array}{l}-0.0429 \\
(-11.47)\end{array}$ & $\begin{array}{l}-0.0701 \\
(-13.80)\end{array}$ & $\begin{array}{l}-0.0781 \\
(-15.46)\end{array}$ & $\begin{array}{l}-0.0886 \\
(-17.31)\end{array}$ & $\begin{array}{l}-0.0718 \\
(-17.34)\end{array}$ & $\begin{array}{l}-0.0579 \\
(-29.76)\end{array}$ & $\begin{array}{l}-0.0508 \\
(-12.47)\end{array}$ \\
\hline$R_{t-1}$ & $\begin{array}{c}0.0255 \\
(7.33)\end{array}$ & $\begin{array}{c}0.0284 \\
(7.82)\end{array}$ & $\begin{array}{c}0.0253 \\
(6.83)\end{array}$ & $\begin{array}{c}0.0253 \\
(6.87)\end{array}$ & $\begin{array}{c}0.0291 \\
(8.44)\end{array}$ & $\begin{array}{c}0.0296 \\
(17.71)\end{array}$ & $\begin{array}{c}0.0166 \\
(5.26)\end{array}$ \\
\hline $\log \left(E_{t-1} / A_{t-1}\right)$ & $\begin{array}{c}0.0204 \\
(4.00)\end{array}$ & $\begin{array}{c}0.0399 \\
(6.33)\end{array}$ & $\begin{array}{l}0.0453 \\
(7.59)\end{array}$ & $\begin{array}{c}0.0420 \\
(6.48)\end{array}$ & $\begin{array}{c}0.0422 \\
(8.78)\end{array}$ & $\begin{array}{c}0.0480 \\
(17.89)\end{array}$ & $\begin{array}{c}0.0322 \\
(6.88)\end{array}$ \\
\hline$R^{2}$ & 0.592 & 0.583 & 0.593 & 0.556 & 0.463 & 0.437 & 0.573 \\
\hline Chow $\chi^{2}$ & & & & & 15.85 & & 10.40 \\
\hline p-value & & & & & 0.001 & & 0.001 \\
\hline Total Observations & & & & & 83,592 & & 84,097 \\
\hline
\end{tabular}

Table ?? reports estimation results of Equation (11) separately for firms with different degree of financial constraints. For the left panel, we sort firms every year, into quintiles based on the value of the Whited and $\mathrm{Wu}(2006)$ index. The right panel reports estimation results of Equation 111) separately for firms with and without rated debt. The data on credit ratings are from Standard and Poor's. The sample period is 1970-2005. The dependent variable is the investment rate $\left(I_{t} / K_{t-1}\right)$. The regressors include lagged values of our baseline measure of idiosyncratic volatility $\left(\sigma_{t-1}\right)$, Tobin's $\mathrm{Q}\left(Q_{t-1}\right)$, operating cashflows $\left(C F_{t-1} / K_{t-2}\right)$, the firm's capital stock relative to the aggregate $\left(\hat{K}_{t-1}=K_{i, t} / \frac{1}{N_{f}} \sum_{i}^{N_{f}} K_{i, t}\right)$, the firm's stock return $\left(R_{t-1}\right)$, and leverage $\left(E_{t-1} / A_{t-1}\right)$. The top panel includes firm effects, the bottom panel includes firm- and timefixed effects. We allow the unobserved firm and time fixed effect to vary across quantiles. The standard errors are clustered at the firm-level, and $t$-statistics are reported in parenthesis. We report the Chow $\chi^{2}$ test and the associated $p$-value for the null that the coefficient on idiosyncratic volatility, $\sigma_{t-1}$, is the same for quintiles 1 and 5 of the WW index, and the same for firms with and without bond rating for the left and right panels respectively. 
Table 11: Effect of Insider Ownership, controlling for Monitoring Quality

\begin{tabular}{|c|c|c|c|c|c|c|c|c|}
\hline Cont. & \multicolumn{4}{|c|}{ Ownership excl. options } & \multicolumn{4}{|c|}{ Ownership incl. options } \\
\hline \multirow{3}{*}{$\mathrm{N}$} & & Insd $=\mathrm{L}$ & $\mathrm{Insd}=\mathrm{H}$ & $p$ & & Insd $=\mathrm{L}$ & $\mathrm{Insd}=\mathrm{H}$ & $p$ \\
\hline & Inst $=\mathrm{L}$ & $\begin{array}{c}-0.0191 \\
(-1.11)\end{array}$ & $\begin{array}{c}-0.0512 \\
(-3.30)\end{array}$ & 0.061 & Inst $=\mathrm{L}$ & $\begin{array}{c}-0.0175 \\
(-0.76)\end{array}$ & $\begin{array}{c}-0.0771 \\
(-2.79)\end{array}$ & 0.034 \\
\hline & Inst $=\mathrm{H}$ & $\begin{array}{c}-0.0306 \\
(-3.18)\end{array}$ & $\begin{array}{c}-0.0367 \\
(-2.75)\end{array}$ & 0.649 & Inst $=\mathrm{H}$ & $\begin{array}{c}-0.0015 \\
(-0.08)\end{array}$ & $\begin{array}{r}-0.0117 \\
(-0.48)\end{array}$ & 0.671 \\
\hline \multirow[t]{2}{*}{$\mathrm{Y}$} & Inst $=\mathrm{L}$ & $\begin{array}{c}\text { Insd }=\mathrm{L} \\
-0.0237 \\
(-1.43)\end{array}$ & $\begin{array}{c}\text { Insd }=H \\
-0.0576 \\
(-3.55)\end{array}$ & $\begin{array}{c}p \\
0.050\end{array}$ & Inst $=\mathrm{L}$ & $\begin{array}{c}\text { Insd }=\mathrm{L} \\
-0.0261 \\
(-1.09)\end{array}$ & $\begin{array}{c}\text { Insd }=H \\
-0.0507 \\
(-2.30)\end{array}$ & $\begin{array}{c}p \\
0.320\end{array}$ \\
\hline & Inst $=\mathrm{H}$ & $\begin{array}{c}-0.0144 \\
(-1.25)\end{array}$ & $\begin{array}{c}-0.0178 \\
(-1.37)\end{array}$ & 0.808 & Inst $=\mathrm{H}$ & $\begin{array}{c}0.0148 \\
(0.61)\end{array}$ & $\begin{array}{c}0.0213 \\
(0.81)\end{array}$ & 0.803 \\
\hline Obs & & & & 34,862 & & & & 11,144 \\
\hline
\end{tabular}

Table ?? reports estimation results of Equation (11) separately for firms with different levels of monitoring quality and levels of insider ownership. We use two measures of monitoring quality, the fraction of shares owned by institutional investors (top panel), and the tangibility of the firm's assets, defined as PPE over Assets. Observations with zero or missing values are excluded. Every year, we first sort firms into three equal sized groups based on institutional ownership (High, Medium, Low), and then sort into into three equal sized groups based on ownership by insiders (High, Medium, Low). We report results for the four corners. The sample period is $1986-2005$. The dependent variable is the investment rate $\left(I_{t} / K_{t-1}\right)$. The regressors include lagged values of our baseline measure of idiosyncratic volatility $\left(\sigma_{t-1}\right)$, Tobin's Q $\left(Q_{t-1}\right)$, operating cashflows $\left(C F_{t-1} / K_{t-2}\right)$, the firm's capital stock relative to the aggregate $\left(\hat{K}_{t-1}=K_{i, t} / \frac{1}{N_{f}} \sum_{i}^{N_{f}} K_{i, t}\right)$, the firm's stock return $\left(R_{t-1}\right)$, and leverage $\left(E_{t-1} / A_{t-1}\right)$. We include firm- and time-fixed effects. We allow the unobserved firm and time fixed effect to vary across quantiles. The standard errors are clustered at the firm-level, and $t$-statistics are reported in parenthesis. We report the Chow $\chi^{2}$ test and the associated $p$-value for the null that the idiosyncratic volatility coefficients, $\sigma_{t-1}$, on each row are the same. 
Table 12: Effect of Competition, controlling for Irreversibility

\begin{tabular}{|c|c|c|c|c|c|c|c|c|}
\hline \multirow[t]{2}{*}{$\begin{array}{l}\text { Irrev. Measure } \\
\end{array}$} & \multicolumn{4}{|c|}{ No Controls } & \multicolumn{4}{|c|}{ With Controls } \\
\hline & & $\mathrm{HH}=\mathrm{L}$ & $\mathrm{HH}=\mathrm{H}$ & $p$ & & $\mathrm{HH}=\mathrm{L}$ & $\mathrm{HH}=\mathrm{H}$ & $p$ \\
\hline \multirow{2}{*}{$\mathrm{RE} / \mathrm{K}$} & Irrev $=\mathrm{L}$ & $\begin{array}{c}-0.0725 \\
(-6.80)\end{array}$ & $\begin{array}{c}-0.0388 \\
(-4.25)\end{array}$ & 0.001 & Irrev $=\mathrm{L}$ & $\begin{array}{r}-0.0637 \\
(-6,03)\end{array}$ & $\begin{array}{c}-0.0232 \\
(-239)\end{array}$ & 0.001 \\
\hline & Irrev $=\mathrm{H}$ & -0.0238 & -0.0462 & 0.024 & Irrev $=\mathrm{H}$ & -0.0305 & -0.0273 & 0.732 \\
\hline Obs & & & & 65,904 & & & & 65,904 \\
\hline \multirow{4}{*}{ Industry $\delta$} & & $\mathrm{HH}=\mathrm{L}$ & $\mathrm{HH}=\mathrm{H}$ & $p$ & & $\mathrm{HH}=\mathrm{L}$ & $\mathrm{HH}=\mathrm{H}$ & $p$ \\
\hline & Irrev $=\mathrm{L}$ & -0.0561 & -0.0507 & 0.626 & Irrev $=\mathrm{L}$ & -0.0616 & -0.0331 & 0.009 \\
\hline & & $(-6.35)$ & $(-5.52)$ & & & $(-6.87)$ & $(-3.65)$ & \\
\hline & Irrev $=\mathrm{H}$ & $\begin{array}{c}-0.0301 \\
(-3.73)\end{array}$ & $\begin{array}{c}-0.0401 \\
(-6.45)\end{array}$ & 0.278 & Irrev $=\mathrm{H}$ & $\begin{array}{c}-0.0273 \\
(-3.50)\end{array}$ & $\begin{array}{c}-0.0169 \\
(-2.74)\end{array}$ & 0.252 \\
\hline Obs & & & & 78,269 & & & & 78,269 \\
\hline \multirow{3}{*}{$\beta^{\text {ind }}$} & & $\mathrm{HH}=\mathrm{L}$ & $\mathrm{HH}=\mathrm{H}$ & $p$ & & $\mathrm{HH}=\mathrm{L}$ & $\mathrm{HH}=\mathrm{H}$ & $p$ \\
\hline & Irrev $=\mathrm{L}$ & -0.0450 & -0.0289 & 0.105 & Irrev $=\mathrm{L}$ & -0.0507 & -0.0139 & 0.003 \\
\hline & Irrev $=\mathrm{H}$ & $\begin{array}{r}-0.0458 \\
(-4.69)\end{array}$ & $\begin{array}{r}-0.0555 \\
(-7.22)\end{array}$ & 0.360 & Irrev $=\mathrm{H}$ & $\begin{array}{c}-0.0525 \\
(-4.95)\end{array}$ & $\begin{array}{r}-0.0428 \\
(-4.95)\end{array}$ & 0.384 \\
\hline Obs & & & & 84,907 & & & & 84,907 \\
\hline
\end{tabular}

Table 12 reports estimation results of Equation 11) separately for firms with different levels of Competition and levels of capital irreversibility. We use the Herfindahl index as a measure of competition. For each panel, we first sort firms every year into three equal sized groups based on different measures of investment reversibility: their rental expenditure normalized by Capital (top panel), the mean depreciation rate of the industry (middle panel) and their beta with the corresponding industry portfolio. Then, we sort into three equal sized groups based on the Herfindahl index of their respective industry. We estimate idiosyncratic volatility and the industry beta from Equation 9 The three groups are labeled (High, Medium, Low) and we report results for the four corners. Industries are defined at the 3-digit SIC code. The sample period is $1970-2005$. The dependent variable is the investment rate $\left(I_{t} / K_{t-1}\right)$. The regressors include lagged values of our baseline measure of idiosyncratic volatility $\left(\sigma_{t-1}\right)$. The left panel contains estimation results without any additional controls and firm-fixed effects. The right panel contains estimation results including the following controls: Tobin's Q $\left(Q_{t-1}\right)$, operating cashflows $\left(C F_{t-1} / K_{t-2}\right)$, the firm's capital stock relative to the aggregate $\left(\hat{K}_{t-1}=K_{i, t} / \frac{1}{N_{f}} \sum_{i}^{N_{f}} K_{i, t}\right)$, the firm's stock return $\left(R_{t-1}\right)$, leverage $\left(E_{t-1} / A_{t-1}\right)$ and yearfixed effects. We allow the unobserved firm and time fixed effect to vary across quantiles. The standard errors are clustered at the firm-level, and $t$-statistics are reported in parenthesis. We report the Chow $\chi^{2}$ test and the associated $p$-value for the null that the idiosyncratic volatility, $\sigma_{t-1}$, coefficients on each row are the same. 